Article

\title{
Economic Voting in Direct Democracy: A Case Study of the 2016 Italian Constitutional Referendum
}

\author{
Arndt Leininger \\ Otto Suhr Institute of Political Science, Freie Universität Berlin, 14195 Berlin, Germany; E-Mail: arndt.leininger@fu-berlin.de
}

Submitted: 15 December 2018 | Accepted: 21 March 2019 | Published: 27 June 2019

\begin{abstract}
Referendums provide citizens with more control over policy. At the same time, they often entail choices over highly complex policies and are politicised along partisan lines, suggesting that partisan rather than policy considerations will guide voters' choices. I look to the 2016 Italian constitutional referendum, which was particularly complex and polarised, as an opportunity to test for mechanisms of government accountability in a referendum. Using a national survey of voters, I show that the more negative a respondent's evaluation of the state of the economy, the lower their likelihood to vote 'yes' on the government's reform proposal. This relationship is remarkably strong: an average respondent with a very positive evaluation of the state of the economy has an $88 \%$ probability of supporting the government's reform proposal compared to only $12 \%$ for a respondent with a very negative evaluation. The fact that economic evaluations are a strong determinant of vote choice provides evidence for the existence of an economic vote in a referendum. This further suggests that voters may treat referendums as a sort of second-order election.
\end{abstract}

\section{Keywords}

direct democracy; economic voting; Italy; referendums; second-order election; voting

\section{Issue}

This article is part of the issue "The Politics, Promise and Peril of Direct Democracy", edited by Todd Donovan (Western Washington University, USA).

(C) 2019 by the author; licensee Cogitatio (Lisbon, Portugal). This article is licensed under a Creative Commons Attribution 4.0 International License (CC BY).

\section{Introduction}

Referendums often entail choices over complex policies and become politicised along partisan lines which suggests that often partisan rather than policy considerations guide voters' choices. The 2016 Italian national referendum on constitutional reform provides a unique opportunity to test this hypothesis. Using a national survey of voters, I show that the more negative a respondent's evaluation of the state of the economy, the lower their likelihood to vote 'yes' on the government's reform proposal. These findings provide evidence for the existence of an economic vote in a direct-democratic setting. I suggest that voters may treat referendums as a sort of second-order election, with referendums acting as an exercise in government accountability inbetween elections.

Referendums provide citizens with more control over policy. While proponents of referendums believe that they can increase the legitimacy of policies, opponents doubt that voters possess the willingness and capacity to inform themselves and make sensible judgements about sometimes complicated and far-reaching decisions. Referendums, especially those concerning substantive issues, effectively allow voters to punish the government in-between elections. One of the most prominent and widely studied determinants of voting for or against the government is the state of the economy. The so-called economic vote implies that voters punish a government for a bad economy and reward it for a good economy (Lewis-Beck \& Stegmaier, 2007).

I embrace the 2016 Italian constitutional referendum, which was particularly complex and polarised, as an opportunity to test for mechanisms of government accountability in a referendum. It is distinguished as a subject for investigation by two advantages: first, it is one of only a few national level referendums to date which have been subject to survey, and second, it shares many common 
characteristics of other national referendums. The government deliberately triggered the referendum and parties took clear stances on the highly complex referendum issue. The polarisation of the campaign between government and opposition along with Renzi's vow to resign if the reform failed provided a clear opportunity for economic voting. Specifically, I ask in this article whether citizens' perceptions of the economy influence how they vote in a referendum.

My analysis is based on data from a survey conducted by the Italian National Election Studies Association (ITANES) project both before and after the 2016 referendum which link respondents' evaluations of the national (as well as their own) economic situation to their vote choice. Results of various specifications and robustness checks consistently show that economic evaluations correlate positively with vote choice: a respondent with a positive evaluation of the economy is on average more likely to vote 'yes' than somebody who has a less favourable view of the economy. This relationship is surprisingly stable and strong. While an average respondent with a very positive evaluation of the economy had an $88 \%$ probability of supporting the government, it is only $12 \%$ for respondents who evaluated the economy very negatively.

The empirical results provide strong evidence for an economic vote in what is an admittedly most-likely case, because the campaign was strongly polarised, and the prime minister tied his political future to the outcome of the vote. Most-likely cases are strong tests of a theory in the sense that a failure to find the hypothesised relationship would cast strong doubts on the theory in general (George \& Bennett, 2004). While this article provides strong evidence for an economic vote in the 2016 Italian constitutional referendum, it remains to be seen whether it extends to other cases as well. For that matter, future research should also incorporate least-likely cases, referendums where parties do not play such a dominant role or are internally divided.

\section{Referendums as Second-Order Elections}

In a referendum, there are no parties or candidates to elect but only an issue to decide. Therefore, Schoen (2012), for instance, cautions that while determinants of participation in elections and referendums may be similar, determinants of vote choices may differ drastically between elections and referendums. Referendums are thought to be on average more volatile than elections because in some referendums "voters must choose among alternatives that are sometimes unfamiliar and [are] perhaps lacking in reliable voting cues", while at other times referendums can be "highly partisan contests, even without the appearance of party or candidate names on the ballot" (LeDuc, 2002, p. 711).

There are many reasons that referendums can be considered more cognitively demanding than elections. They often involve complex and sometimes technical matters and confront citizens with issues that may be new and unfamiliar to them. Additionally, because less is at stake in a referendum, citizens may exert less effort to inform themselves about the issue at hand. Not surprisingly then, much of the research on voting behaviour in referendums has focused on the issue of voter competence. One of the main findings in this line of research is that low-information voters can mimic informed voters' choices by relying on cues from governments, parties and interest groups (Christin, Hug, \& Sciarini, 2002; Clarke, Elliott, \& Stewart, 2017; Lupia, 1994).

Work in this vein assumes that voters who possess factual information about politics in general or a particular referendum, take sensible decisions, or less normatively charged decisions, in their own interest. However, it is not clear whether possessing information about a ballot proposition translates into an informed vote. Knowledgeable voters also tend to be more ambivalent about the referendum issues they have to decide upon (Lanz \& Nai, 2014; Nai, 2014)-more information does not necessarily make it easier to decide. These papers and the literature they stand for are all based on the assumption that voters do vote on the issues on the ballot. Either they try to weigh the arguments themselves, or they rely on cues to mimic informed decision-making. In the following section, I will provide an alternative viewpoint, which suggests that voters treat referendums, particularly those that are polarised along partisan lines as in the Italian case, quite similar to second-order elections.

Second-order election, a term popularised by Reif and Schmitt (1980) to describe the elections to the European Parliament, denotes any election that can be considered subordinate to the electoral contest that serves to form the national government-in parliamentary systems, the national parliamentary election would be the first-order election, and in presidential systems it would be the presidential election that is first-order. The second order elections model postulates that issues and cleavages of the national first-order contest will largely determine the vote in the second-order contest as well. Specifically, governing parties will lose votes relative to the preceding first-order election.

European elections, despite an increase in the powers of the EU, and in particular the European Parliament, continue to be characterised as second-order to national elections (Schmitt, 2005; Schmitt \& Teperoglou, 2015). Coming to the Italian case then, it is reasonable to assume that in spite of Italy's relatively extensive experience with national referendums, that these are secondorder to (first-order) national elections. The outcome of the 2016 referendum mirrored the characteristics of a typical second-order election in the sense that turnout was lower than in the preceding national election and the governing parties lost the vote.

The point of this article is not to show that electoral politics dominate referendum policy but rather that they are sufficiently important to have an impact on the vote-similar to what one would see in a second-order 
electoral contest. The specific argument I make in this article is that we should also be able to see an economic vote in a referendum. Just as Okolikj and Quinlan (2016) who have shown that an economic vote can also be observed in European parliament elections. The next section discusses the concept of economic voting and how it might apply to referendums more generally and the 2016 Italian constitutional referendum in particular.

\section{Economic Voting in Referendums}

The so-called economic vote is one of the most important paradigms in electoral research. While the economic vote has developed into a literature of considerable breadth and variety (see, for instance, Duch \& Stevenson, 2008; Kayser, 2014), so far it has only rarely been considered in referendum research. To the best of my knowledge, only two contributions to date have estimated an economic vote in referendums; however, with entirely different interpretations and contradictory expectations.

Bowler and Donovan (1998) see the economic vote rooted in risk aversion; they suggest that voters may ask themselves: is this a good time for the state to adopt a new policy? Their analysis is based on survey data on three 1990 California and a 1992 Colorado state referendum and shows a significant correlation between economic evaluations and vote choice, but only for less educated voters and only for some ballot propositions. They take these findings to mean that less-educated voters are more likely to engage in economic voting to make up for a lack of political sophistication. Uncertainty about the consequences of a proposal may lead voters to stick with the status quo rather than voting for a change, which may be why proposals to change the status quo are often defeated (LeDuc, 2003).

In contrast, Jenssen (1998, p. 195), seeking to understand divergent outcomes of three EU membership referendums in the Nordic countries Sweden, Finland and Norway, hypothesizes that "economic hardship led a majority in Sweden and Finland to vote for changein this case EU membership-whereas better-off Norwegian voters preferred things as they were". However, in almost perfect contradiction of that hypothesis, economic evaluations correlated positively with a vote for EU membership in all countries surveyed.

Although these authors do estimate an economic vote in a sense, their approach is divorced from the original paradigm as applied in electoral research. Their interpretation of the economic vote is seemingly inspired by the literature on cue-taking: voters use external information to make up their mind on an issue on the ballot. However, voting in line with one's preferred party recommendation might just be voting for that party. If political parties take visible and differing positions on a referendum, it might take on the character of a second-order election. Such a perspective takes seriously the possibility that voters treat referendums as an opportunity to vent dissatisfaction with the government.
Economic voting is one of the most important mechanisms of government accountability. I argue in this article that it can also be at work in a referendum. Economic voting is in a sense also more broadly applicable than cue-taking because those without a partisan attachment cannot rely on cues. However, they are easily able to engage in economic voting. In the Italian case analysed here, about a quarter of voters have no partisan affiliation but almost all of them voice an opinion on the state of the economy.

The economy is the most important issue for a large majority of voters in most, if not all, elections. Rather than being positional, it is a valence issue. This means voters agree that they all prefer a good economic situation, stable economic growth and low unemployment and inflation rates, to a bad one. The basic idea underlying the paradigm is that voters hold the reigning government responsible for the economic situation. If it is good, they will reward the government by voting for the governing party or parties, and if it is bad, they will punish the government by choosing one of the opposition parties (Lewis-Beck \& Stegmaier, 2000, p. 138).

The economic vote is largely retrospective (LewisBeck \& Stegmaier, 2013; Wlezien, 2015), the process being as follows: first, voters evaluate the economic situation; they then decide whether to attribute the responsibility to the government to the economic situation and, finally, they punish or reward it with their vote. In this way, voters in elections in large part evaluate government performance in retrospect. This perspective does not apply in the same way in a referendum. Here, the choice at hand seems to be more prospective in nature: what are the anticipated consequences of the proposed policy? Are these consequences deemed desirable? This might explain why the economic vote has been reinterpreted in the two contributions discussed above not as a retrospective evaluation of government performance, but as a prospective calculation of the merits of changing the status quo.

Nevertheless, one can still apply the concept of the economic vote to referendums without engaging in conceptual stretching. Voters can easily identify both a government's position in a referendum as well as the state of the economy. Parties often take sides in referendum campaigns, and the sides they take often mirror a government-opposition divide. Sometimes, even the head of government's fate rests implicitly or explicitly, as in the Italian case, on the outcome of the referendum. Therefore, voters may, as they do in elections, choose to reject the government's position in economically bad times and, vice versa, approve it in good times. Alternatively, we might think that if a citizen is dissatisfied with the government's handling of the economy that they do not put trust in the quality of a constitutional reform formulated and propagated by that same government.

Adapting the economic voting paradigm to direct democracy, I hypothesise that the more positive a voters evaluation of the economic situation, the more likely 
they are to vote for the government's position. Formulated differently with the Italian case in mind: the more positive a respondent's evaluation of the economic situation of the country, the more likely it is that they vote 'yes' (in favour of the constitutional reform) in the referendum. Having laid out the expectations for the empirical analysis, in the following section, I briefly present the reform proposal put to a vote, the political situation leading up to the vote and the campaign accompanying it, before going on to describe the research design.

\section{The Italian Constitutional Referendum 2016}

On 4 December 2016 eligible Italian citizens were asked to vote on a constitutional law which would amend Italy's Constitution to change the composition and powers of the parliament as well as the division of powers between the federal state, the regions and other administrative units. Besides the rather pragmatic reason of data availability, the referendum is a particularly useful case for study for three reasons. ${ }^{1}$

First, the subject of the referendum was a constitutional reform. Such referendums are a common occurrence at the national level. Secondly, the referendum was triggered by the government, as are most national referendums. Finally, the referendum campaign became polarised along partisan lines, pitting the governing parties against essentially all opposition parties.

Unlike other West European states, Italy does not have a differentiated system of two chambers. The Italian Constitution stipulates that both houses of parliament are equal in rights. This institutional arrangement has long been regarded as a problem because policymaking is hampered by laws circulating endlessly between the two chambers with neither chamber having the ability to override the other. This also implies that the government is dependent on the trust of both chambers. Hence, after the parliamentary elections in Italy in 2013, which led to differing majorities in the two parliamentary chambersthe social-democratic Partito Democratico (PD) won an absolute majority in the House, but no party won a majority in the Senate-a political crisis ensued. President Giorgio Napolitano, urged by almost all party leaders to stay on for another term to moderate the crisis (Pasquino \& Valbruzzi, 2017, p. 148), appointed Enrico Letta of the PD to lead a grand coalition between the PD and the Popolo della Libertà (PdL), a merger of Silvio Berlusconi's Forza Italia and the radical right party Alleanza Nazionale. He tasked that coalition with reforming bicameralism and the electoral system.

Only a year after his appointment Letta was replaced as prime minister by the PD's then party secretary Matteo Renzi after an internal party leadership challenge. Renzi inherited Letta's commitment to reform and would later reference Napolitano's call for reform to justify the need for and the content of his reform proposal (Pasquino \& Valbruzzi, 2017, p. 148). Earlier, the PD's coalition partner PdL had split with some ministers and MPs leaving the government and re-joining Forza Italia, while others founded the Nuovo Centrodestra (NCD) and continued in government. Just before becoming prime minister, Renzi, then still party secretary of the PD, reached an agreement with Berlusconi's Forza Italia, the so-called Nazarene Pact, that assured Forza Italia's support. However, Berlusconi withdrew his party from the agreement in February 2015 when Renzi unilaterally put forward Sergio Mattarella as a candidate for President of the Republic who was subsequently elected. The government, and in particular Prime Minister Matteo Renzi, nevertheless pressed on with its plans for reform.

The reform package aimed at simplifying the institutional architecture, speeding up the legislative process and reducing the cost of government. It foresaw a reorganisation of territorial structure, foremost the elimination of the provinces and the National Council for Economics and Labour (CNEL), an advisory body to the government. It would abolish Italy's symmetric bicameralism by reducing the Senate's power and size and making it an indirectly elected body.1 Besides the institutional goal of streamlining and centralising the political system, Renzi also pursued a political goal. Having acquired the prime ministership through an intra-party leadership challenge, his "goal was to show to the opposition and, perhaps even more so, to those within the PD who were challenging his reforms and his policies, that he enjoyed the support of a large majority of the Italian people" (Pasquino \& Valbruzzi, 2017, p. 153).

The constitutional reform, also named Riforma RenziBoschi, after its initiators Prime Minister Matteo Renzi, and the responsible minister for constitutional reforms and relations with the parliament Maria Elena Boschi, was passed by the Senate on 13 October 2015 and by the lower house, the Chamber of Deputies, on 11 January 2016. Both houses confirmed their votes on 20 January 2016 and 12 April 2016 respectively. The two parliamentary chambers approved the reform with an absolute majority which, however, fell short of a two-thirds majority. This created a situation where the reform failed in parliament, but the parliamentary vote opened a path to a referendum according to article 138 of the Italian Constitution. The referendum was held on 4 December 2016, and the following question was put to the eligible population of Italy:

Do you approve the text of the Constitutional Law concerning 'Provisions for overcoming equal bicameralism, reducing the number of Members of Parliament, limiting the operating costs of the institutions, the suppression of the CNEL and the revision of Title $V$ of Part II of the Constitution' approved by Parliament

\footnotetext{
${ }^{1}$ As outlined above, few referendums are subject to scientific survey and even fewer of these include questions on the state of the economy (for an exception, see Curtis, Jupille, \& Leblang, 2014). The ITANES survey used in this paper is unique because of the breadth of items related to the economy included in the questionnaire.
} 
and published in the Official Gazette no. 88 of 15 April 2016? (Wikipedia, n.d.) ${ }^{2}$

Therefore, if voters wanted to approve the reform they had to vote 'yes', and 'no' to reject it. Voter turnout was $65.5 \%$, which is relatively high for a constitutional referendum - only 9.7 points less than the last national election in 2013 and about 13 points more than the last constitutional referendum in 2006. Voters rejected the reform by a substantial margin. $59.1 \%$ voted against the reform and only $40.9 \%$ in favour. In almost all regions, except for Emilia-Romagna, Toscana and Trentino-Alto Adige, a majority of voters voted against the referendum. The former two regions are strongholds of the PD while the latter is a stronghold of the CD, the junior member of the governing coalition (Pasquino \& Valbruzzi, 2017, p. 154). This aggregate pattern provides a first indication that this vote was not just about constitutional reform but also about the current government of the time.

The referendum campaign was described as "unusually bitter and protracted" (Pasquino \& Valbruzzi, 2017, p. 153). It pitted the governing parties against essentially all opposition parties. In addition to the authors of the reforms, Matteo Renzi's centre-left PD, their coalition partner the NCD supported the reforms as well as the leftist Christian Democrats of the Centro Democratico (CD). So did the liberal party Scelta Civica and the anti-corruption parties Italia dei Valori and Radicali Italiani. The reforms were most strongly opposed by the MoVimento 5 Stelle (five-star movement) led by comedian Beppe Grillo. Further opponents of the reform included regional and rightwing parties such as the Lega Nord or Forza Italia, but also some left-wing parties such as Sinistra Italiana or the Partito della Rifondazione Comunista.

Many associations and interest groups partook in the campaign. Early on the National Association of Italian Partisans announced its opposition to the reform. They were joined by the leftist trade union CGIL and a wide range of committees for a 'no'-vote that sprang up, most importantly "Libertà e Giustizia". On the other side, the national association of employers Confindustria, the farmers' association Coldiretti and the Christian democratic trade union CISL campaigned for a 'yes'. Unusually, the President of the Italian Republic, Giorgio Napolitano, took a public stance in favour of the reform. Experts were divided on the issue. As a testament to the complexity of the issue, in the months leading up to the vote, a dozen books were published in which scientists and other experts on legal and institutional matters argued for or against the reforms, while others, in turn, took on a more neutral tone seeking to inform rather than influence the general public (Ceccarini \& Bordignon, 2017, p. 290).

In short, the referendum was preceded by a monthslong intensive campaign, which was politicised along par- tisan lines. The referendum turned into a vote on the population's satisfaction with the government, not least because Renzi promised to resign if he were to lose the referendum. Early in the campaign, Renzi tied his political future to the outcome of the vote in the hope that his (initial) popularity would carry the reform to success. While his approval was already down to $40 \%$ (from initially more than $70 \%$ ) at the time he made the announcement in April 2016, he still was the most popular leader. Consequently, after losing the referendum, Renzi announced his resignation immediately after the result became known. At the request of the Italian President Sergio Mattarella, Renzi postponed his resignation until after the following year's budget was passed on 7 December 2016. In a sense, Renzi lost not a parliamentary, but a popular vote of confidence in his government.

\section{Research Design}

The 2016 Italian constitutional referendum was covered by a scientific survey fielded by the ITANES project. The data were collected in a two-wave panel survey (pre- and post-referendum) of the Italian population. The survey comprised 3050 respondents in total. My analysis will focus on voters in the referendum only, therefore disregarding non-voters as well as voters casting a blank ballot. I use list-wise deletion in case of missing values on any of the dependent or independent variables.

The dependent variable is a respondent's vote choice, measured as vote intention in the pre-referendum wave and as recall question in the post-referendum wave. Both measures are not without their problems. As far as the item in the pre-referendum questionnaire is concerned: vote intentions may change, and some respondents may voice a vote intention although in the end they will not participate. As far as the post-referendum questionnaire is concerned: there is strong over-reporting of participation and likely a bandwagoning effect. It is, however, hard to gauge to what extent this creates bias. A comparison of the aggregated survey data with the actual referendum outcome indicates that vote intentions, while still predicting 'no' to win, predict a much closer outcome than actually occurred. However, a substantial number of voters reported not having made up their minds yet. While strongly overstating turnout, reported vote choices are more accurate, overestimating the 'no'vote only slightly (see Table 1 ).

Since vote intentions are more inaccurate than reported vote choices, I rely on reported vote choices from the post-referendum wave. In alternative specifications, vote intentions instead of choices are used as robustness check reported in the Appendix I (see Table A2). Both variables are coded as dummy variables which are 1 if a respondent voted or intended to vote 'yes' (for the consti-

\footnotetext{
${ }^{2}$ English translation from Wikipedia and accuracy confirmed by an Italian colleague. Italian original obtained from the Ministry of the Interior (http://www.interno.gov.it/it/italiani-voto-referendum-costituzionale): “Approvate il testo della legge costituzionale concernente 'disposizioni per il superamento del bicameralismo paritario, la riduzione del numero dei parlamentari, il contenimento dei costi di funzionamento delle istituzioni, la soppressione del CNEL e la revisione del Titolo V della parte II della Costituzione', approvato dal Parlamento e pubblicato nella Gazzetta Ufficiale n. 88 del 15 aprile 2016?"
} 
Table 1. Vote intentions obtained from the pre-referendum wave, the actual result of the vote and reported vote choices obtained from the post-referendum wave.

\begin{tabular}{lllll}
\hline & Yes & No & Undecided & Turnout \\
\hline Pre-referendum wave & $36.4 \%$ & $39.7 \%$ & $23.9 \%$ & $65.6 \%$ \\
Actual result & $40.9 \%$ & $59.1 \%$ & & $89 \%$ \\
Post-referendum wave & $38.9 \%$ & $61.1 \%$ & & \\
\hline
\end{tabular}

tutional reform) and 0 if they voted or intended to vote 'no' (against the constitutional reform).

The key independent variable is a respondent's retrospective evaluation of the national economy. Respondents were asked to complete the following sentence 'do you think the economic situation in Italy in the last year...' using one of the following answers: 'improved a lot', 'improved somewhat', 'remained equal', 'little worse', 'much worse' or 'don't know?' (see Appendix II for details). This question was asked in both the preand post-referendum waves. I use the answers from the pre-referendum wave to avoid that evaluations may be coloured by the referendum result or a respondent's own vote choice.

In Appendix I, I present results for the same specifications replacing economic evaluations from the first wave with evaluations from the second wave. Respondents' evaluations of their economic situation are only available in the post-referendum questionnaire. The literature on economic voting in elections almost unanimously suggests that sociotropic voting, voting based on assessments of the national economy, is stronger than egotropic voting, voting based on one's own economic situation (Lewis-Beck \& Stegmaier, 2013). Nevertheless, it is interesting to explore whether this holds for referendums as well. Hence, I include variations of my main models testing for egotropic economic voting in Appendix I.

This study is based on cross-sectional survey data, as are most other individual levels studies of economic voting. I correlate differences in the perception of the economic situation between individuals with their vote choice or intention. However, this must mean that some of the interviewees are wrong in their assessment of the economic situation. For the national economy cannot be both good and bad at the same time. One prime reason for these differences in the assessment of the overall economic situation may be a respondent's party identification. Early on, Kramer (1983), a pioneer of economic voting, pointed out that supporters of the governing party or parties tend to view the economic situation more positively than adherents of the opposition party or parties. Thus, the question is whether a greater consistency of results in individual-level studies, vis-à-vis studies based on aggregate data, is not ultimately an artefact of the endogeneity of perceptions of the economic situation.

The concern that political preferences colour economic evaluations is at least partly alleviated by the fact that I use economic perceptions measured before the referendum. Therefore, the outcome of the referendum could not have influenced respondents' economic perceptions. In addition, I control for partisanship as well in additional specifications, such as vote choice in the last national election, government approval, and the popularity of the prime minister (Table 3 ). I recoded party identification and vote choice in the last national election into dummy variables that indicate whether a respondent identifies with or voted for one of the governing parties at the time of the referendum.

Respondents' factual knowledge about the referendum was measured by their answers to three questions asking about details of the constitutional reform and what the quorum for the referendum was. Respondents are presented with three possible answers per question. I take the sum of correct answers ( 0 to 3 ) to derive an index of referendum knowledge. I interact this variable with respondents' economic evaluations in the second model to test hypothesis 2 (see Table 3 ). I also include approval of the government in general and the Prime Minister Matteo Renzi more specifically in some specifications. Here, respondents were asked to rate Renzi or his government on a scale from 0 to $10(0=$ completely negative judgement; 10 = completely positive view). I also include a respondent's gender, their age and education level. The latter is captured by a dummy variable indicating whether a respondent has attended university or is currently doing so. Table 2 presents summary statistics for the key variables.

Binary logistic regression will be used throughout. The dependent variable is a dummy variable indicating whether respondents voted in favour of the proposed constitutional reform ('yes' $=1$ ) or against it ('no' $=0$ ). In a first specification, I regress a respondent's vote choice on their retrospective sociotropic economic evaluation to test whether economic evaluations predict vote choice. Further specifications, included in Table 3, add measures of partisanship as control variables to assess the robustness of these findings. In a second set of models, reported in Table 4, I test for an economic vote in three separate groups of respondents: voters who identify with one of the governing parties, voters who identify with one of the opposition parties and voters who do not identify with any party. This probes whether the economic vote is conditioned by partisanship.

\section{Results}

My empirical results indicate a strong and persistent economic vote in the 2016 Italian constitutional referendum. 
Table 2. Summary statistics for the variables included in the models presented in Table 3.

\begin{tabular}{|c|c|c|c|c|c|}
\hline Variable & $\mathbf{N}$ & Mean & St. Dev. & Min & Max \\
\hline Vote choice & 2716 & 0.39 & 0.49 & 0 & 1 \\
\hline Sociotropic economy & 3020 & 2.58 & 0.88 & 1 & 5 \\
\hline PID (Government) & 3050 & 0.23 & 0.42 & 0 & 1 \\
\hline Vote (Government) & 2907 & 0.13 & 0.34 & 0 & 1 \\
\hline Government approval & 2977 & 3.83 & 2.76 & 0 & 10 \\
\hline Approval (PM) & 2864 & 3.59 & 3.08 & 0 & 10 \\
\hline Referendum knowledge & 3049 & 1.59 & 1.05 & 0 & 3 \\
\hline Age & 3027 & 48.06 & 17.12 & 18 & 88 \\
\hline Female & 3027 & 0.48 & 0.50 & 0 & 1 \\
\hline University education & 3027 & 0.34 & 0.47 & 0 & 1 \\
\hline
\end{tabular}

Table 3. Model (1) correlates a respondent's vote choice with their evaluation of the national economy; further models add partisanship (2), (3) vote choice in the last national election, (4) government approval, or (5) approval of the prime minister as control variable.

\begin{tabular}{|c|c|c|c|c|c|}
\hline & \multicolumn{5}{|c|}{ Dependent variable: } \\
\hline & \multicolumn{5}{|c|}{ Vote choice (Yes) } \\
\hline & (1) & $(2)$ & (3) & (4) & (5) \\
\hline \multirow[t]{2}{*}{ Sociotropic economy } & $1.00 * * *$ & $.73 * * *$ & $.99 * * *$ & $.17^{* *}$ & $.36^{* * *}$ \\
\hline & $(.06)$ & $(.06)$ & $(.06)$ & $(.07)$ & $(.07)$ \\
\hline \multirow[t]{2}{*}{ Referendum knowledge } & $.07 *$ & -.02 & .05 & $.15^{* * *}$ & $.15^{* * *}$ \\
\hline & $(.04)$ & $(.05)$ & $(.05)$ & $(.05)$ & $(.05)$ \\
\hline \multirow[t]{2}{*}{ PID (Government) } & & $2.66 * * *$ & & & \\
\hline & & $(.13)$ & & & \\
\hline \multirow[t]{2}{*}{ Vote (Government) } & & & $1.14^{* * *}$ & & \\
\hline & & & $(.13)$ & & \\
\hline \multirow[t]{2}{*}{ Government approval } & & & & $.57 * * *$ & \\
\hline & & & & $(.03)$ & \\
\hline \multirow[t]{2}{*}{ Approval PM } & & & & & $.44 * * *$ \\
\hline & & & & & $(.02)$ \\
\hline \multirow[t]{2}{*}{ Female } & -.01 & -.04 & -.01 & -.05 & -.07 \\
\hline & $(.09)$ & $(.10)$ & $(.09)$ & $(.10)$ & $(.11)$ \\
\hline \multirow[t]{2}{*}{ Age } & $.02 * * *$ & $.01 * *$ & $.01^{* * *}$ & $.01^{* * *}$ & $.01 * * *$ \\
\hline & $(.003)$ & $(.003)$ & $(.003)$ & $(.003)$ & $(.003)$ \\
\hline \multirow[t]{2}{*}{ University education } & $.20 * *$ & .07 & $.17^{*}$ & .07 & .10 \\
\hline & $(.09)$ & $(.10)$ & $(.09)$ & $(.10)$ & $(.11)$ \\
\hline \multirow[t]{2}{*}{ Constant } & $-4.07 * * *$ & $-3.35 * * *$ & $-3.98 * * *$ & $-4.19 * * *$ & $-3.84 * * *$ \\
\hline & $(.23)$ & $(.25)$ & $(.24)$ & $(.26)$ & $(.26)$ \\
\hline Observations & 2,682 & 2,682 & 2,572 & 2,656 & 2,567 \\
\hline Log Likelihood & $-1,573.14$ & $-1,299.71$ & $-1,472.11$ & $-1,227.44$ & $-1,221.48$ \\
\hline
\end{tabular}

Notes: $* p<0.1 ; * *<0.05 ; * * p<0.01$.

A respondent's evaluation of the economy shows a significant positive association with their probability of supporting the constitutional reform (Table 3). The more positively a respondent evaluated the national economic situation in the past year, the more likely they were to vote 'yes'. Because coefficients from a logistic regression do not lend themselves to straightforward interpretation, I also plot the predicted probabilities (Figure 1). A respondent who evaluates the national economy very negatively has only a $12 \%$ probability of supporting the constitutional reform, while somebody who rates the state of the national economy to be very good has a probability of $88 \%$ to vote 'yes' - a 76-point difference. A regression model including respondents' evaluations of the national economy fares considerably better in predicting a respondent's vote choice than a model which does not, leading to a proportional reduction in error of around $21 \%$ compared to the simpler model not including economic evaluations (see Tables A13 and A14).

Because economic evaluations can be considered both a cause and a consequence of partisan preferences, in models (2) to (5) I add a range of measures of a vot- 
Table 4. Models correlate a respondent's vote choice with their evaluation of the national economy, separately for subgroups of respondents with a party identification with one of the governing parties (column 1), with no party identification (2) and with a party identification with one of the parties in opposition (3).

\begin{tabular}{lccc}
\hline & \multicolumn{3}{c}{ Subgroups: } \\
\cline { 2 - 4 } & PID (Government) & PID (None) & PID (Opposition) \\
\hline Sociotropic economy & $(1)$ & $(2)$ & $.83^{* * *}(.13)$ \\
Knowledge & $.54^{* * *}(.15)$ & $-.05(.10)$ & $-.08(.07)$ \\
Female & $-.05(.13)$ & $-.21(.20)$ & $-.10(.15)$ \\
Age & $-.47^{*}(.25)$ & $.01^{*}(.01)$ & $.002(.004)$ \\
University education & $.03^{* * *}(.01)$ & $-.22(.20)$ & $.22(.16)$ \\
Constant & $.09(.24)$ & $-2.78^{* * *}(.51)$ & $-3.43^{* * *}(.37)$ \\
\hline Observations & $-1.01(.62)$ & 559 & 1,393 \\
Log Likelihood & 647 & -347.97 & -598.26 \\
\hline
\end{tabular}

Notes: ${ }^{*} p<0.1 ;{ }^{* *} p<0.05 ;{ }^{* *} p<0.01$.

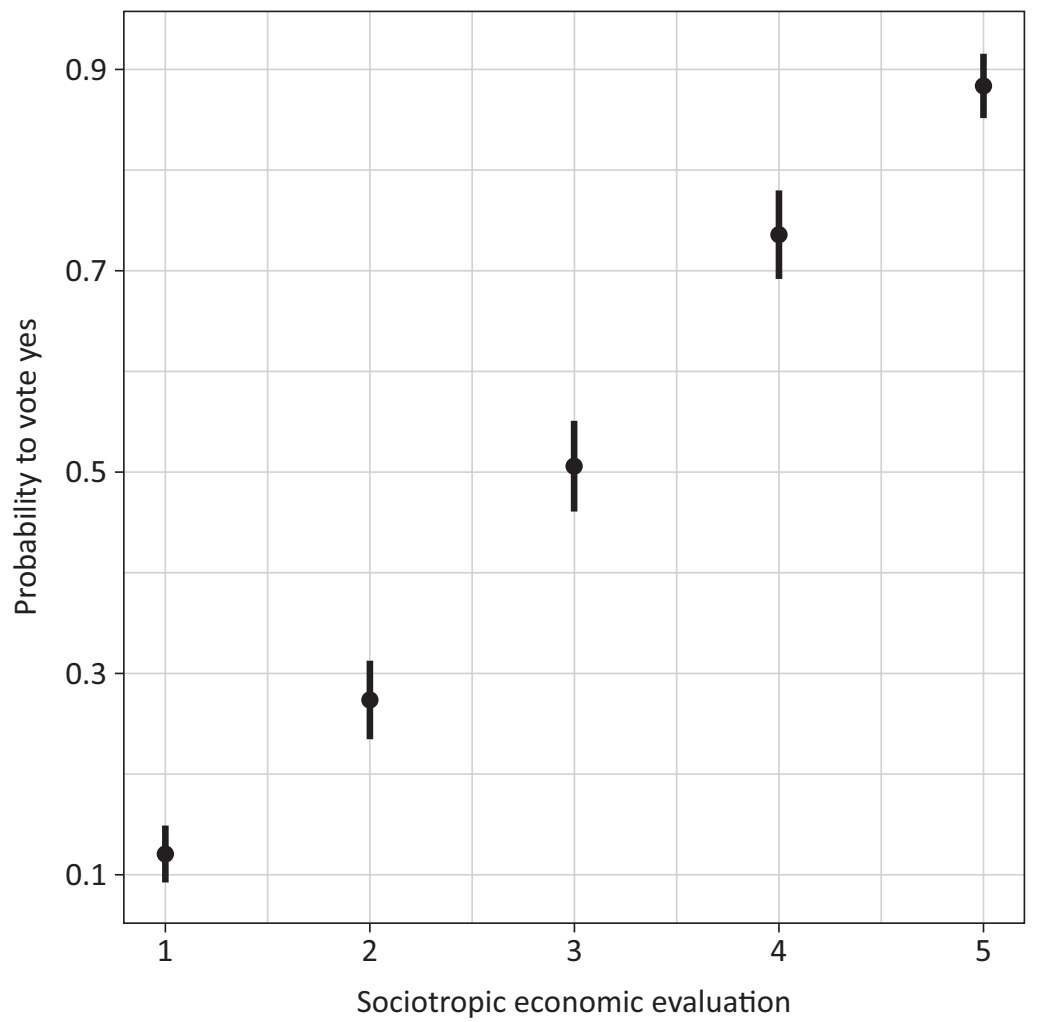

Figure 1. Predicted probabilities for a woman of median age (48) with a university degree to vote 'yes' in the referendum dependent on whether she thinks the national economy (1) got much worse, (2) got a little worse, (3) remained equal, (4) improved somewhat or (5) improved a lot, based on model 1, Table 3.

ers' partisan disposition. When these variables are included as additional explanatory variables the coefficient on economic evaluations is substantially reduced but remains significant. These results should alleviate concerns that economic evaluations are simply a proxy for respondents' partisan predispositions. Economic evaluations correlate with vote choices even when controlling for government approval. Results are also robust to using vote choice in the last national election, government approval, or approval of Prime Minister Matteo Renzi (see Table 3). This is also reflected in the predicted probabilities associated with these models. As shown in Appendix I, a hypothetical female voter of median age with a university degree who, for instance, neither approves nor disapproves of the government is more likely to vote for or against the reform depending on her evaluation of the state of the economy (see Figure A2).

These results hold up in alternative specifications, where I use vote intentions instead of reported vote choices, sociotropic economic evaluations measured after the referendum instead of before the referendum, replace sociotropic with egotropic economic evaluations, 
and add a voter's distance on the left-right scale to Renzi's PD (see Tables A2, A3, A4 and A5). For egotropic evaluations, the partial correlation with vote choices is weaker, but not by much (see also Table A6). This is in line with the findings of economic voting literature, which generally finds assessments of the national economy to be more predictive of vote choices than respondents' personal economic situation.

Including government approval as an additional explanatory variable leads to the most substantial reduction in the coefficient on economic evaluations. ${ }^{3}$ However, if one assumes that economic evaluations are causally prior to government approval, then one can consider the latter as a mediating factor. Put otherwise, this reflects the view that government approval is an influence on an individual's vote choice, which is itself influenced by economic evaluations. A simple back-of-theenvelope calculation based on the mediation procedure proposed by Baron and Kenny (1986) allows me to differentiate between a direct and indirect effect of economic evaluations on vote choice and to calculate the relative importance of these two channels. As it turns out, both channels contribute about equally to the total economic vote. $47 \%$ of the correlation between economic evaluations and vote choice, captured in model 1 in Table 3, is a direct effect and the remaining 53\% an indirect effect mediated through government approval. I will discuss these results further in the discussion.

The inclusion of partisanship in model 2 in Table 3 implies a comparison between, on the one hand, voters who indicated identifying with one of the governing parties and, on the other hand, voters who either identified with one of the opposition parties or had no partisan at- tachment at all. In total, $24 \%$ of respondents who voted in the referendum did not identify with a political party. The crucial difference between the latter two groups of voters is that those without partisan attachment are not able to rely on partisan cues. However, $99 \%$ of those nonpartisans were able to provide an assessment of the national economy. Hence, while they are not able to follow partisan cues, they can cast an economic vote.

Therefore, rather than merely treating partisanship as a control variable, I also estimate separate models for partisans of the government, partisans of the opposition and non-partisans to look into the possibility that the strength of the economic vote varies between these groups (Table 4). These results show that all groups of voters engaged in economic voting, meaning that within those three groups, respondents with a more negative assessment of the economic situation were less likely to vote for the reform than those with a more positive assessment. The difference in voting behaviour between those with negative and positive assessments was greatest among the group of non-partisans, suggesting that those lacking partisan cues most strongly relied on an economic vote. These results also hold up in alternative specifications, which replace reported vote choices with vote intentions, sociotropic economic evaluations measured before the referendum with sociotropic economic evaluations measured after the referendum, and which replace sociotropic with egotropic economic evaluations (see Tables A8 to A11).

To facilitate an interpretation of the substantive significance of these results in Figure 2 plots the predicted probabilities for the three models in Table 4. When comparing the plots, two patterns become apparent: the pre-
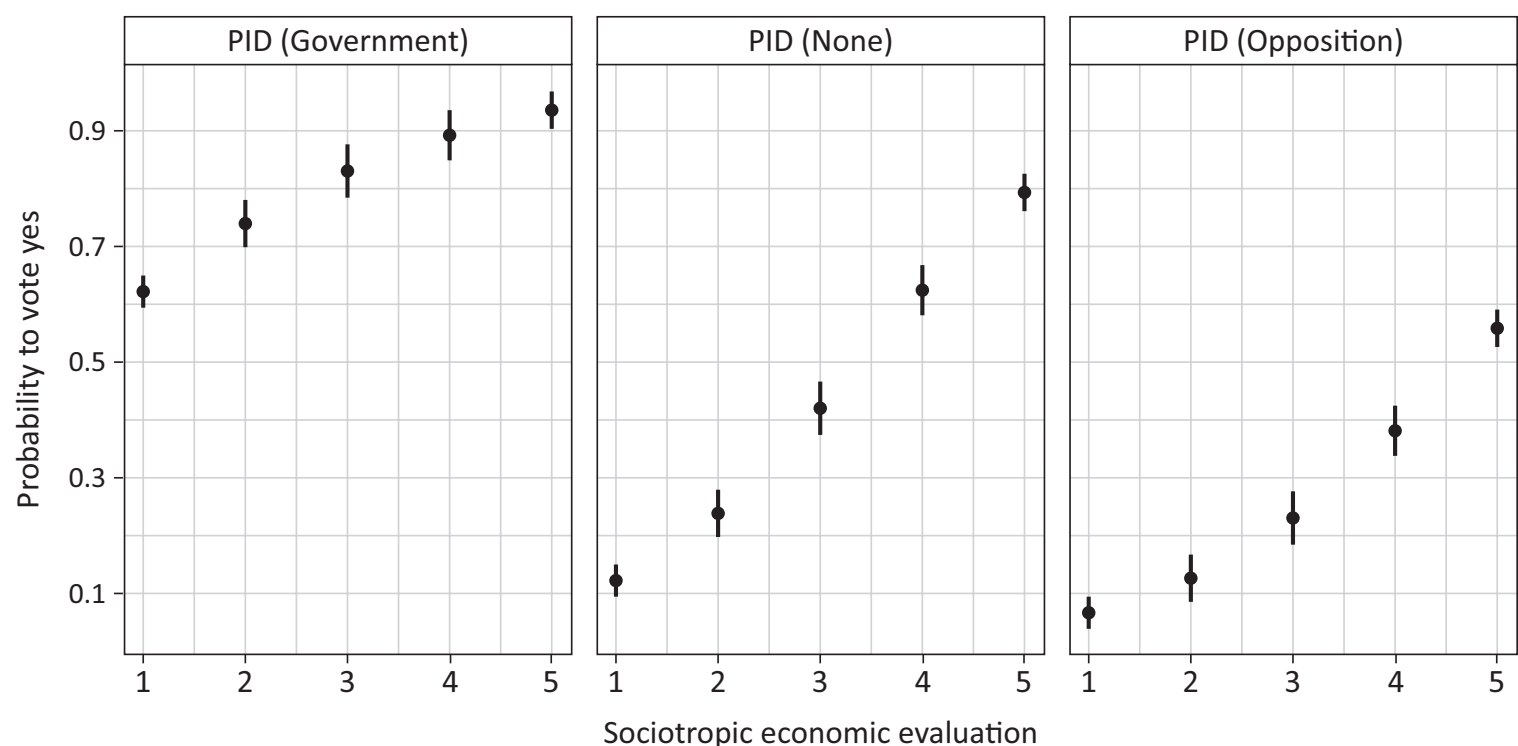

Figure 2. Predicted probabilities for three hypothetical women of median age (48) with a university degree to vote 'yes' in the referendum dependent on whether they think the national economy (1) got much worse, (2) got a little worse, (3) remained equal, (4) improved somewhat or (5) improved a lot, based on models 1 to 3 in Table 4.

\footnotetext{
${ }^{3}$ Given the cross-sectional nature of the data, this is nothing more than assumption made to support the calculations that follow. These calculations should be treated as merely descriptive and illustrative.
} 
dicted voting patterns differ in levels and slopes. Firstly, independent of their views of the economy, supporters of the government are of course on average much more likely to vote for the reform than non-partisans and supporters of the opposition. Secondly, the relationship between economic evaluations and vote choice is strongest in the group of non-partisans. In this group, the difference between very negative and very positive evaluations amounts to a full 67 points, while the difference is 49 points among opposition and only 31 points among government supporters. However, these differences in the correlation between economic evaluations and vote choice between groups are not statistically significant (see Table A7 in Appendix I, in which I present the relevant formal test in form of a model interacting economic evaluations with the categorical PID variable, which is functionally equivalent to the subgroup analyses, presented here. The interaction terms are not statistically significant). The main take-away here is that economic voting occurs within all groups.

To summarise, these results are in agreement with the theoretical argument made earlier in this article. However, that argument is admittedly not the only possible interpretation of these results, as I will discuss in the next section.

\section{Discussion}

In the previous section, I have demonstrated a persistent and robust correlation between economic perceptions and vote choice. This is not to say that economic evaluations were the only or even the most important determinant of vote choices; however, the results presented here provide robust evidence in line with my argument that referendums can turn into a sort of secondorder election if they become polarised along partisan lines. Following the government-versus-opposition logic of the campaign, voters showed a marked tendency towards economic voting.

However, one must acknowledge that the empirical results do not dictate the exact interpretation of this economic vote. Specifically, Bowler and Donovan (1998, chapter 4) suggest a different frame for interpreting findings such as my own. They argue that when faced with a choice between an uncertain outcome-in this case, ballot initiatives-and a more certain outcome-keeping the status quo-voters tend to be risk-averse. The authors connect this reasoning to the literature on economic voting by arguing that the state of the economy provides information that influences risk aversion. In line with their argument, their findings based on multiple referendum surveys show that voters who hold more positive evaluations of the economic situation are more likely to vote to change the status quo.

Following Bowler and Donovan (1998), one could interpret the results presented in this article as being (partially) driven by status quo bias. Uncertainty about the consequences of the reform package in combination with a negative economic evaluation may have led voters to stick with the status quo. In that case, my interpretation of having witnessed an economic vote in an unusual second-order election would be mistaken. However, these two interpretations are neither theoretically nor empirically in contradiction with each other.

Theoretically, it is perfectly possible that some voters look to the state of the economy to judge whether it is a good time to risk changing the status quo, while others treat the referendum as a second-order election, an opportunity to punish the government. It is also possible that both considerations play a role in an individual voter's mind. Empirically, I have shown that economic evaluations are predictive of vote choice even when controlling for measures of a respondent's orientation towards the government. One could take this to imply that both mechanisms played a role in the 2016 Italian referendum. Specifically, one could argue that the correlation between economic evaluations and vote choice obtained after controlling for government approval, which is substantially reduced but still significant, represents a heuristic economic vote as Bowler and Donovan (1998, chapter 4) frame it.

Adjudicating more conclusively between the two arguments is, unfortunately, beyond the scope of this single case study. Therefore, it is impossible to disentangle whether voters who rejected the reform rejected it based on a change in the status quo or the government's position. Given the specifics of the Italian case and the empirical results presented in this article, however, it seems safe to say that the referendum took on the character of a second-order election in which voters exercised an economic vote, although this does not rule out risk aversion as an alternative mechanism. Concerning the Italian case, risk aversion was probably not an essential factor. Two surveys carried out after the referendum indicated that more than four-fifths of respondents were open to changing the constitution and four-fifths of 'no'voters were open to reforms to make the system more efficient (Ceccarini \& Bordignon, 2017, p. 295).

\section{Conclusions}

In this article, I analysed the relationship between individuals' assessments of the national as well as their personal economic situation and their vote choice in the 2016 Italian constitutional reform based on a survey conducted by the ITANES project. I have chosen to adopt the economic voting paradigm to study voting in this referendum because the campaign was strongly polarised along partisan lines, not least because Prime Minister Matteo Renzi, the architect of the reform, promised to resign if he lost the referendum. ${ }^{4}$

As expected, the more positive a respondent's evaluation of the economy, the higher their likelihood to vote 'yes' on the referendum proposed by the govern-

\footnotetext{
${ }^{4}$ One can of course only speculate as to whether the economic vote would have been as strong as it was if Renzi had not tied his future to the referendum.
} 
ment. This relationship is surprisingly strong and stable. These results concur with Pasquino and Valbruzzi's (2017, p. 155) verdict that 'a significant portion of the electorate decided to punish the government'. When thinking about referendums more broadly, the Italian constitutional referendum of 2016 can be considered a mostlikely case for an economic vote-the polarisation of the campaign between government and opposition along with Renzi's commitment to resign if the reform failed provided a clear opportunity for economic voting. In the logic of case studies, a most-likely case exhibits characteristics that make a theoretically predicted outcome very likely. Most-likely cases are strong tests of a theory in the sense that a failure to find the hypothesised relationship would cast strong doubts on the theory in general (George \& Bennett, 2004).

Having established the relevance of an economic vote in this particular case, the question now is whether it can also be found in least-likely cases, referendums where parties do not take a dominant role, are internally divided or both of these situations are present. Future research should, in cases studies of least-likely cases or in comparative studies, extend the economic voting paradigm to other referendums and test whether it replicates in other contexts. This could be complemented by aggregate data research, building on early research by Bowler and Donovan (1998) that seeks to establish whether referendums are more likely to pass in economically good times. One important question such research could address is whether an economic vote also occurs when a government takes the position to uphold the status quo in a referendum. That question can only be answered by also looking at referendums where the government defends the status quo (against an initiative, for instance). Ideally, one would study multiple referendums that provide variation in the government's position in a referendum to understand more fully whether an economic vote in a referendum is a form of status quo bias, or government accountability. Lastly, having likened referendums to second-order election raises the question whether the outcome of a referendum also depends on its relative position in the (first-order) electoral cycle, as is the case for second-order elections.

If future research finds the economy to be a relevant factor in referendum voting more generally, then where in the business cycle a referendum is held could be a determinant of its outcome. In the Italian case, a majority of respondents believed that the economy had not improved over the past year and only about every tenth respondent thought the economy had gotten better. Clearly, given that voters' perceptions of the economy were such a strong predictor of vote choice this was not a good time for Renzi to achieve institutional reform by referendum. In a sense, this poses a catch-22 for any political leader pursuing reform: Renzi advocated reforms for a more efficient government as a means of addressing Italy's economic woes. However, it was precisely the economic situation, which he hoped to alleviate, that kept him from implementing his plans for reform.

\section{Acknowledgments}

I thank Kathrin Ackermann, Christopher Anderson, JeanBenoit Pilet, Gil Pradeau and Denise Traber as well as participants at the Empirical Political Science colloquium at the University of Mainz, and the "Democratic Anxieties" workshop, also held in Mainz, NIG Annual Work Conference 2017, MPSA 2018, ECPR Joint Sessions 2018 and EPSA 2018 for very helpful comments and suggestions.

\section{Conflict of Interests}

The author declares no conflict of interests.

\section{References}

Baron, R. M., \& Kenny, D. A. (1986). The moderatormediator variable distinction in social psychological research: Conceptual, strategic, and statistical considerations. Journal of Personality and Social Psychology, 51(6), 1173-1182.

Bowler, S., \& Donovan, T. (1998). Demanding choices: Opinion, voting, and direct democracy. Ann Arbor, MI: University of Michigan Press.

Ceccarini, L., \& Bordignon, F. (2017). Referendum on Renzi: The 2016 vote on the Italian constitutional revision. South European Society and Politics, 22(3), 281-302.

Christin, T., Hug, S., \& Sciarini, P. (2002). Interests and information in referendum voting: An analysis of Swiss voters. European Journal of Political Research, 41(6), 759-776.

Clarke, H., Elliott, E., \& Stewart, M. (2017). Heuristics, heterogeneity and green choices: Voting on California's proposition 23. Political Science Research and Methods, 5(4), 755-774.

Curtis, K. A., Jupille, J., \& Leblang, D. (2014). Iceland on the rocks: The mass political economy of sovereign debt resettlement. International Organization, 68(3), 721-740.

Duch, R. M., \& Stevenson, R. T. (2008). The economic vote. How political and economic institutions condition election results (political economy of institutions and decisions). Cambridge: Cambridge University Press.

George, A. L., \& Bennett, A. (2004). Case studies and theory development in the social sciences. Cambridge, MA: MIT Press.

Jenssen, A. T. (1998). Personal economies and economic expectations. In M. Gilljam, P. Pesonen, \& A. Jenssen Todal (Eds.), To join or not to join: Three Nordic referendums on membership in the European Union (pp. 194-214). Oslo: Scandinavian University Press.

Kayser, M. A. (2014). The elusive economic vote. In L. LeDuc, R. G. Niemi, \& P. Norris (Eds.), Comparing 
democracies (Vol. 4, pp. 112-132). Thousand Oaks, CA: Sage.

Kramer, G. H. (1983). The ecological fallacy revisited: Aggregate- versus individual-level findings on economics and elections, and sociotropic voting. American Political Science Review, 77(1), 92-111.

Lanz, S., \& Nai, A. (2014). Vote as you think: Determinants of consistent decision making in direct democracy. Swiss Political Science Review, 21(1), 119-139.

LeDuc, L. (2002). Opinion change and voting behaviour in referendums. European Journal of Political Research, 41(6), 711-732.

LeDuc, L. (2003). The politics of direct democracy: Referendums in global perspective. Peterborough, ON: Broadview Press.

Lewis-Beck, M. S., \& Stegmaier, M. (2000). Economic determinants of electoral outcomes. Annual Review of Political Science, 3(1), 183-219.

Lewis-Beck, M. S., \& Stegmaier, M. (2007). Economic models of voting. In R. J. Dalton \& H. Klingemann (Eds.), The Oxford handbook of political behavior. Oxford: Oxford University Press.

Lewis-Beck, M., \& Stegmaier, M. (2013). The VP-function revisited: A survey of the literature on vote and popularity functions after over 40 years. Public Choice, 157(3/4), 367-385.

Lupia, A. (1994). Shortcuts versus encyclopedias: Information and voting behavior in California insurance reform elections. American Political Science Review, 88(1), 63-76.

Nai, A. (2014). The Cadillac, the mother-in-law, and the ballot: Individual and contextual roots of ambivalence in Swiss direct democracy. Electoral Studies, 33, 292-306.

\section{About the Author}

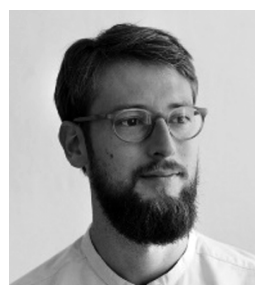

Arndt Leininger is a Research Fellow at the Chair for Political Sociology of Germany at Freie Universität Berlin. His areas of research are comparative politics and applied quantitative methods. Arndt is interested in direct democracy, turnout, election forecasting, economic voting and electoral studies more broadly. His work has been published in Political Science Research and Methods, Electoral Studies and Research and Politics, amongst others.
Okolikj, M., \& Quinlan, S. (2016). Context matters: Economic voting in the 2009 and 2014 European parliament elections. Politics and Governance, 4(1), 145-166.

Pasquino, G., \& Valbruzzi, M. (2017). Italy says no: The 2016 constitutional referendum and its consequences. Journal of Modern Italian Studies, 22(2), 145-162.

Reif, K., \& Schmitt, H. (1980). Nine second-order national elections: A conceptual framework for the analysis of European election results. European Journal of Political Research, 8(1), 3-44.

Schmitt, H. (2005). The European parliament elections of June 2004: Still second-order? West European Politics, 28(3), 650-679.

Schmitt, H., \& Teperoglou, E. (2015). The 2014 European parliament elections in Southern Europe: secondorder or critical elections? South European Society and Politics, 20(3), 287-309.

Schoen, H. (2012). Wählen und abstimmen: Zwei Seiten einer Medaille? Eine Analyse am Beispiel des Volksentscheids zum Nichtraucherschutz in Bayern [Voting in elections and referendums: Two sides of the same coin? An analysis using the example of the referendum on the protection of non-smokers in Bavaria]. Politische Vierteljahresschrift Sonderheft, 45, 514-535.

Wikipedia. (n.d.). 2016 Italian constitutional referendum. Wikipedia. Retrieved from https://en.wikipedia.org/ wiki/2016_Italian_constitutional_referendum

Wlezien, C. (2015). The myopic voter? The economy and US presidential elections. Electoral Studies, 39, 195-204. 


\section{Appendix I}

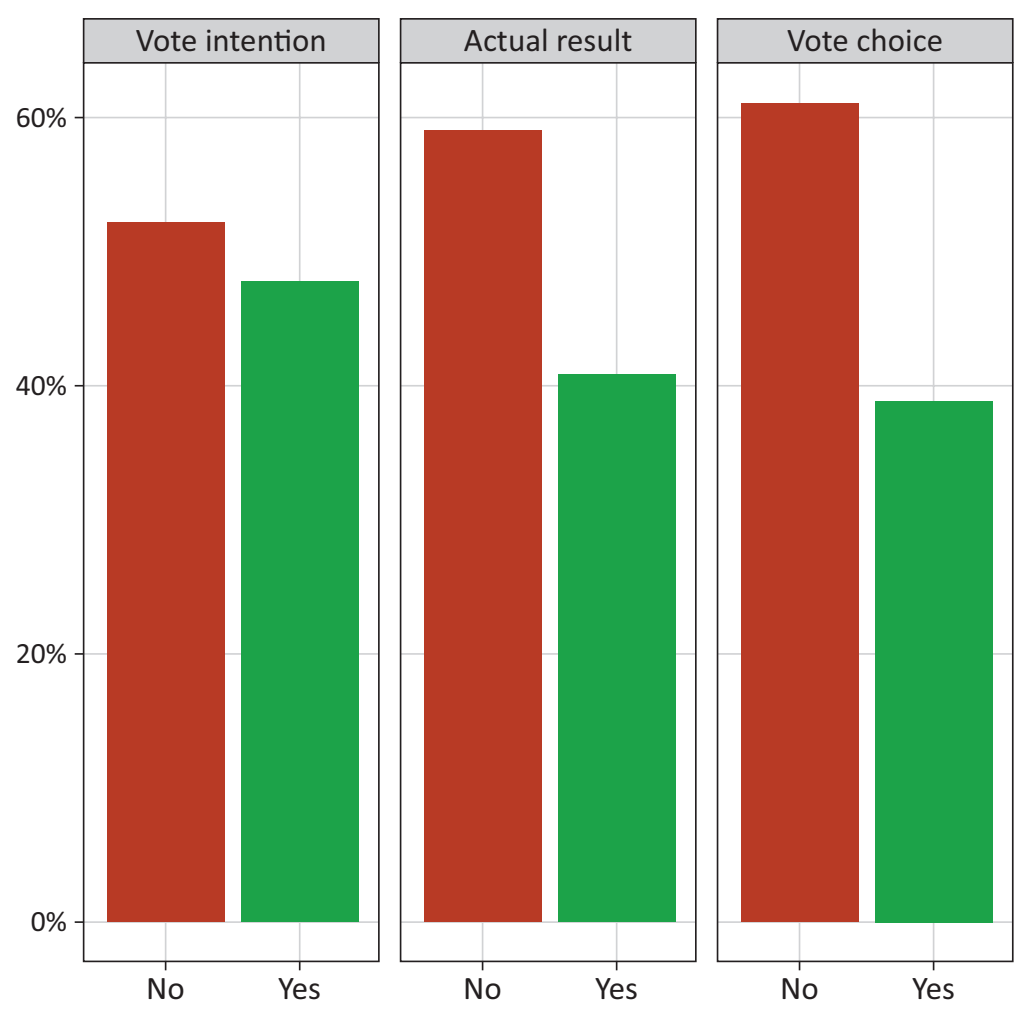

Figure A1. Aggregated share of vote intentions for and against the constitutional reform (ignoring undecided voters and non-voters), the actual result of the referendum, and the aggregate reported vote choices (ignoring those who casted a blank ballot or abstained). 

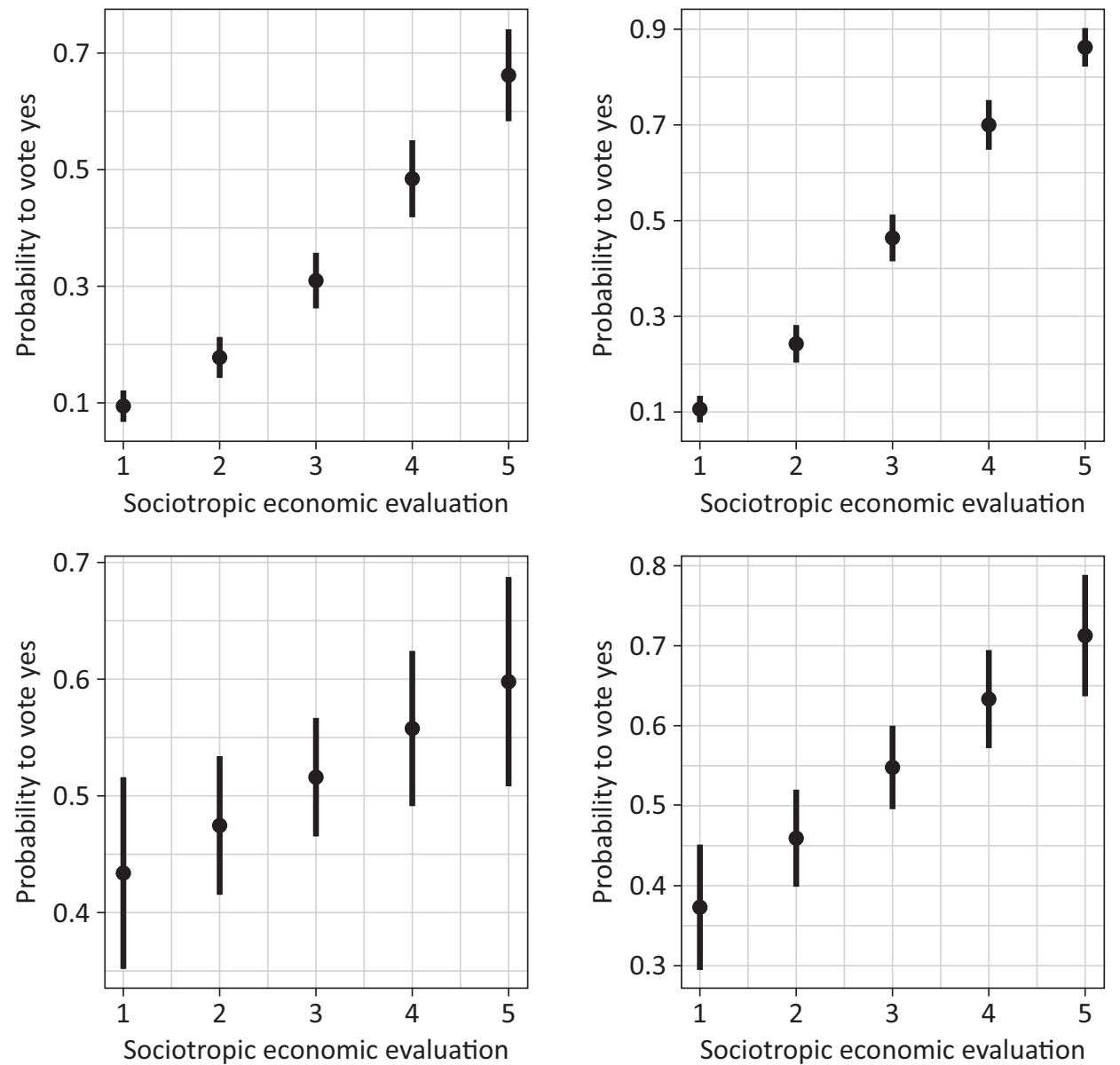

Figure A2. Top left: predicted probabilities for a woman of median age (48) with a university degree and no partisan identifiction with a governing party (5) to vote "Yes" in the referendum dependent on whether she thinks the national economy (1) got much worse, (2) got a little worse, (3) remained equal, (4) improved somewhat or (5) improved a lot, based on model (2) in Table 1 in the manuscript. Top right: predicted probabilities for the same hypothetical woman who did not voted for one of the governing parties in the last national elections, based on model (3). Bottom left: predicted probabilities for the same hypothetical woman who neither approves nor disapproves of the government, based on model (4). Bottom right: predicted probabilities for the same hypothetical woman who neither approves nor disapproves of the prime minister, based on model (5).
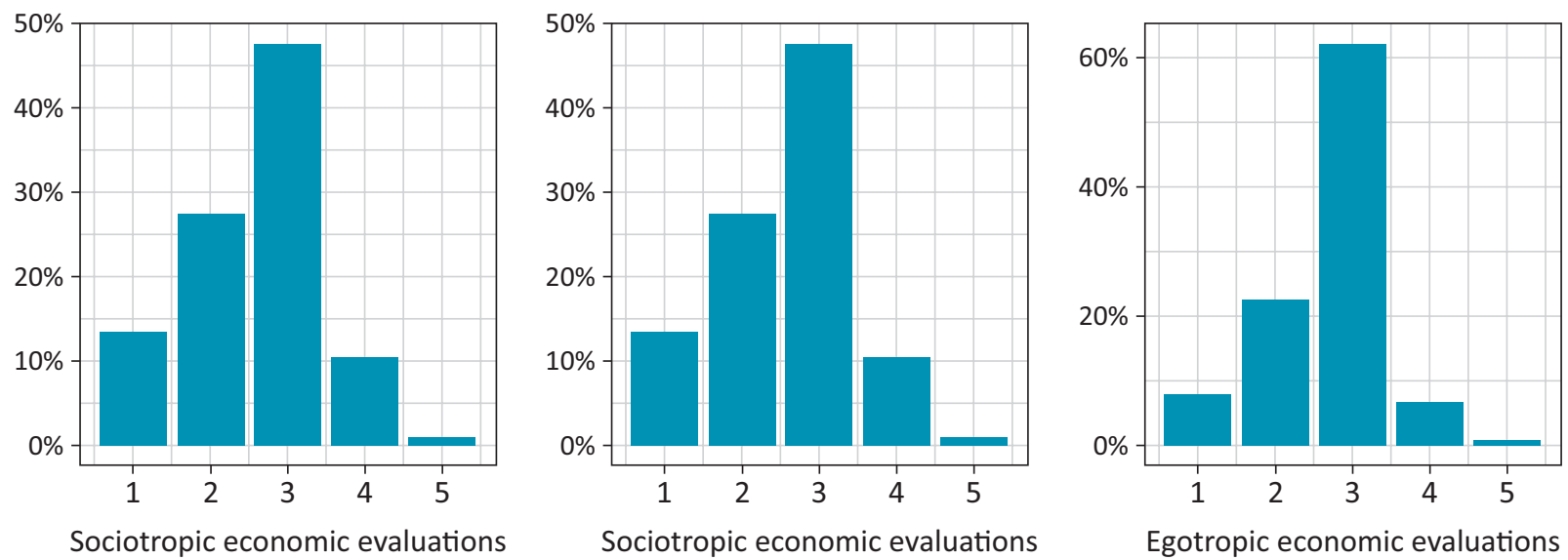

Figure A3. Distributions of economic evaluations: (from left to right) sociotropic economic evaluations (from the pre-referendum wave), sociotropic economic evaluations (from the post-referendum wave) and egotropic economic evaluations. 
Table A1. Mediation analysis: model 1 replicates model (1) from Table 1 in the manuscript; model (2) regresses government approval on economic evaluations and control variables; and model (3) replicates model (4) from Table 1 in the manuscript. All models are OLS regression models (linear probability models in case of models (1), and (3)).

\begin{tabular}{|c|c|c|c|}
\hline & \multicolumn{3}{|c|}{ Dependent variable: } \\
\hline & $\begin{array}{l}\text { Vote choice (Yes) } \\
\text { (1) }\end{array}$ & $\begin{array}{c}\text { Government approval } \\
\text { (2) }\end{array}$ & $\begin{array}{c}\text { Vote choice (Yes) } \\
\text { (3) }\end{array}$ \\
\hline Sociotropic economy & $\begin{array}{l}.20 * * * \\
(.01)\end{array}$ & $\begin{array}{l}1.80 * * * \\
(.05)\end{array}$ & $\begin{array}{l}.02 * * \\
(.01)\end{array}$ \\
\hline Government approval & & & $\begin{array}{l}.10 * * * \\
(.003)\end{array}$ \\
\hline Referendum knowledge & $\begin{array}{c}.01^{*} \\
(.01)\end{array}$ & $\begin{array}{l}-.05 \\
(.04)\end{array}$ & $\begin{array}{l}.02 * * * \\
(.01)\end{array}$ \\
\hline Female & $\begin{array}{c}-.003 \\
(.02)\end{array}$ & $\begin{array}{c}.03 \\
(.09)\end{array}$ & $\begin{array}{l}-.01 \\
(.02)\end{array}$ \\
\hline Age & $\begin{array}{l}.003^{* * *} \\
(.001)\end{array}$ & $\begin{array}{l}.01 * * * \\
(.003)\end{array}$ & $\begin{array}{l}.002 * * * \\
(.0005)\end{array}$ \\
\hline University education & $\begin{array}{l}.04^{* *} \\
(.02)\end{array}$ & $\begin{array}{l}.32 * * * \\
(.09)\end{array}$ & $\begin{array}{c}.01 \\
(.02)\end{array}$ \\
\hline Constant & $\begin{array}{l}-.31 * * * \\
(.04)\end{array}$ & $\begin{array}{l}-1.36^{* * *} \\
(.19)\end{array}$ & $\begin{array}{l}-.17^{* * *} \\
(.04)\end{array}$ \\
\hline Observations & 2,682 & 2,943 & 2,656 \\
\hline $\mathrm{R}^{2}$ & .15 & .34 & .35 \\
\hline
\end{tabular}

Notes: ${ }^{*} \mathrm{p}<0.1 ; * * \mathrm{p}<0.05 ; * * * \mathrm{p}<0.01$

Table A2. Replication of models 1 to 5 from Table 1 in the manuscript. All models replace vote choice with vote intentions.

\begin{tabular}{|c|c|c|c|c|c|}
\hline & & & ident varial & & \\
\hline & & & intention $(Y$ & & \\
\hline & (1) & $(2)$ & (3) & (4) & (5) \\
\hline Sociotropic economy & $1.15^{* * *}$ & $.85 * * *$ & $1.12 * * *$ & .09 & $.28 * * *$ \\
\hline & $(.07)$ & $(.08)$ & $(.07)$ & $(.10)$ & $(.09)$ \\
\hline Referendum Knowledge & $-.44 * * *$ & $-.61 * * *$ & $-.46 * * *$ & $-.59 * * *$ & $-.62 * * *$ \\
\hline & $(.06)$ & $(.06)$ & $(.06)$ & $(.07)$ & $(.07)$ \\
\hline PID (Government) & & $2.62 * * *$ & & & \\
\hline & & $(.17)$ & & & \\
\hline Vote (Government) & & & $.92 * * *$ & & \\
\hline & & & $(.17)$ & & \\
\hline Government approval & & & & $.68 * * *$ & \\
\hline & & & & $(.03)$ & \\
\hline Approval PM & & & & & $.61 * * *$ \\
\hline & & & & & $(.03)$ \\
\hline Female & $.23 * *$ & $.22^{*}$ & $.20^{*}$ & .22 & .23 \\
\hline & $(.11)$ & $(.13)$ & $(.12)$ & $(.14)$ & $(.14)$ \\
\hline Age & $.01^{*}$ & -.003 & .004 & -.0001 & -.01 \\
\hline & $(.003)$ & $(.004)$ & $(.003)$ & $(.004)$ & $(.004)$ \\
\hline University education & .04 & -.12 & .05 & -.22 & $-.27^{*}$ \\
\hline & $(.11)$ & $(.13)$ & $(.11)$ & $(.14)$ & $(.14)$ \\
\hline Constant & $-2.72 * * *$ & $-1.72 * * *$ & $-2.60 * * *$ & $-1.95 * * *$ & $-1.59 * * *$ \\
\hline & $(.27)$ & $(.29)$ & $(.28)$ & $(.32)$ & $(.33)$ \\
\hline Observations & 1,768 & 1,768 & 1,720 & 1,766 & 1,745 \\
\hline Log Likelihood & $-1,027.80$ & -862.99 & -981.01 & -724.78 & -693.10 \\
\hline
\end{tabular}

Notes: ${ }^{*} p<0.1 ;{ }^{* *} p<0.05 ;{ }^{* * *} p<0.01$. 
Table A3. Replication of models 1 to 5 from Table 1 in the manuscript. All models replace sociotropic evaluations measured before the referendum with sociotropic evaluations measured after the referendum.

\begin{tabular}{|c|c|c|c|c|c|}
\hline & \multicolumn{5}{|c|}{ Dependent variable: } \\
\hline & \multicolumn{5}{|c|}{ Vote choice (Yes) } \\
\hline & (1) & $(2)$ & (3) & (4) & (5) \\
\hline \multirow[t]{2}{*}{ Sociotropic economy(after referendum) } & $1.29 * * *$ & $.96 * * *$ & $1.27 * * *$ & $.54 * * *$ & $.71 * * *$ \\
\hline & $(.06)$ & $(.07)$ & $(.07)$ & $(.08)$ & $(.07)$ \\
\hline \multirow[t]{2}{*}{ Referendum Knowledge } & .03 & -.04 & .01 & $.11 * *$ & $.11^{* *}$ \\
\hline & $(.05)$ & $(.05)$ & $(.05)$ & $(.05)$ & $(.05)$ \\
\hline \multirow[t]{2}{*}{ PID (Government) } & & $2.49 * * *$ & & & \\
\hline & & $(.13)$ & & & \\
\hline \multirow[t]{2}{*}{ Vote (Government) } & & & $1.09 * * *$ & & \\
\hline & & & $(.14)$ & & \\
\hline \multirow[t]{2}{*}{ Government approval } & & & & $.52 * * *$ & \\
\hline & & & & $(.03)$ & \\
\hline \multirow[t]{2}{*}{ Approval PM } & & & & & $.39 * * *$ \\
\hline & & & & & $(.02)$ \\
\hline \multirow[t]{2}{*}{ Female } & -.02 & -.05 & -.03 & -.04 & -.07 \\
\hline & $(.09)$ & $(.10)$ & $(.10)$ & $(.11)$ & $(.11)$ \\
\hline \multirow[t]{2}{*}{ Age } & $.02 * * *$ & $.01 * * *$ & $.01 * * *$ & $.01 * * *$ & $.01 * * *$ \\
\hline & $(.003)$ & $(.003)$ & $(.003)$ & $(.003)$ & $(.003)$ \\
\hline \multirow[t]{2}{*}{ University education } & $.22 * *$ & .10 & $.17^{*}$ & .07 & .10 \\
\hline & $(.09)$ & $(.11)$ & $(.10)$ & $(.11)$ & $(.11)$ \\
\hline \multirow[t]{2}{*}{ Constant } & $-4.91 * * *$ & $-4.01 * * *$ & $-4.79 * * *$ & $-5.04 * * *$ & $-4.74 * * *$ \\
\hline & $(.25)$ & $(.27)$ & $(.26)$ & $(.28)$ & $(.28)$ \\
\hline Observations & 2,679 & 2,679 & 2,571 & 2,650 & 2,564 \\
\hline Log Likelihood & $-1,474.46$ & $-1,254.61$ & $-1,384.37$ & $-1,198.07$ & $-1,182.76$ \\
\hline
\end{tabular}

Notes: $* * p<0.05 ; * * p<0.01$. 
Table A4. Models (1) to (5) replicate the models in Table 1 in the manuscript but replace a respondent's sociotropic economic evaluation with their evaluation of their own economic situation (egotropic).

\begin{tabular}{|c|c|c|c|c|c|}
\hline & & & endent variab & & \\
\hline & & & te Choice (Yes & & \\
\hline & (1) & $(2)$ & (3) & (4) & (5) \\
\hline Egotropic economy & $.95 * * *$ & $.70 * * *$ & $.91 * * *$ & $.35 * * *$ & $.50 * * *$ \\
\hline & $(.07)$ & $(.08)$ & $(.07)$ & $(.08)$ & $(.08)$ \\
\hline Referendum knowledge & .06 & -.04 & .05 & $.13^{* * *}$ & $.14^{* * *}$ \\
\hline & $(.04)$ & $(.05)$ & $(.04)$ & $(.05)$ & $(.05)$ \\
\hline PID (Government) & & $2.80 * * *$ & & & \\
\hline & & $(.13)$ & & & \\
\hline Vote (Government) & & & $1.20 * * *$ & & \\
\hline & & & $(.13)$ & & \\
\hline Government approval & & & & $.58 * * *$ & \\
\hline & & & & $(.02)$ & \\
\hline Approval (PM) & & & & & $.45 * * *$ \\
\hline & & & & & $(.02)$ \\
\hline Female & -.05 & -.08 & -.06 & -.06 & -.11 \\
\hline & $(.09)$ & $(.10)$ & $(.09)$ & $(.10)$ & $(.11)$ \\
\hline Age & $.01 * * *$ & $.01 * *$ & $.01 * * *$ & $.01^{* * *}$ & $.01 * * *$ \\
\hline & $(.003)$ & $(.003)$ & $(.003)$ & $(.003)$ & $(.003)$ \\
\hline University education & $.28 * * *$ & .13 & $.24 * * *$ & .07 & .11 \\
\hline & $(.09)$ & $(.10)$ & $(.09)$ & $(.11)$ & $(.11)$ \\
\hline Constant & $-3.94 * * *$ & $-3.27^{* * *}$ & $-3.79 * * *$ & $-4.74 * * *$ & $-4.33 * * *$ \\
\hline & $(.25)$ & $(.28)$ & $(.26)$ & $(.30)$ & $(.30)$ \\
\hline Observations & 2,689 & 2,689 & 2,579 & 2,658 & 2,572 \\
\hline Log Likelihood & $-1,647.76$ & $-1,327.45$ & $-1,541.75$ & $-1,217.66$ & $-1,215.44$ \\
\hline
\end{tabular}

Notes: $* * p<0.05 ; * * p<0.01$. 
Table A5. Models (1) to (5) replicate the models in Table 1 in the manuscript but, additionally, includes a respondents' distance on the left-right scale to Matteo Renzi's Partito Democratico (PD). It is calculated as absolute distance, treating deviations on left and right equally because the referendum was opposed from parties the right and to the left of the PD. The position of the PD is based on a respondent's own assessment elicited in the survey.

\begin{tabular}{|c|c|c|c|c|c|}
\hline & \multicolumn{5}{|c|}{ Dependent variable: } \\
\hline & \multicolumn{5}{|c|}{ Vote choice (Yes) } \\
\hline & (1) & $(2)$ & (3) & (4) & (5) \\
\hline \multirow[t]{2}{*}{ Sociotropic economy } & $1.00 * * *$ & $.61 * * *$ & $.78 * * *$ & .08 & $.23 * * *$ \\
\hline & $(.06)$ & $(.07)$ & $(.07)$ & $(.08)$ & $(.08)$ \\
\hline \multirow[t]{2}{*}{ Referendum knowledge } & $.07^{*}$ & -.06 & -.03 & .08 & $.10^{*}$ \\
\hline & $(.04)$ & $(.06)$ & $(.05)$ & $(.06)$ & $(.06)$ \\
\hline \multirow[t]{2}{*}{ LR distance } & & $-.21 * * *$ & $-.32 * * *$ & $-.23 * * *$ & $-.25 * * *$ \\
\hline & $(.02)$ & $(.02)$ & $(.03)$ & $(.03)$ & \\
\hline \multirow[t]{2}{*}{ PID (Government) } & & $2.24 * * *$ & & & \\
\hline & & $(.14)$ & & & \\
\hline \multirow[t]{2}{*}{ Vote (Government) } & & & $.90 * * *$ & & \\
\hline & & & $(.15)$ & & \\
\hline \multirow[t]{2}{*}{ Government approval } & & & & $.53 * * *$ & \\
\hline & & & & $(.03)$ & \\
\hline \multirow[t]{2}{*}{ Approval PM } & & & & & $.39 * * *$ \\
\hline & & & & & $(.02)$ \\
\hline \multirow[t]{2}{*}{ Female } & -.01 & -.13 & -.07 & -.11 & -.15 \\
\hline & $(.09)$ & $(.12)$ & $(.11)$ & $(.12)$ & $(.12)$ \\
\hline \multirow[t]{2}{*}{ Age } & $.02 * * *$ & $.01 * *$ & $.01 * * *$ & $.01 * * *$ & $.01^{* * *}$ \\
\hline & $(.003)$ & $(.003)$ & $(.003)$ & $(.003)$ & $(.003)$ \\
\hline \multirow[t]{2}{*}{ University education } & $.20 * *$ & -.01 & .05 & .04 & .06 \\
\hline & $(.09)$ & $(.12)$ & $(.11)$ & $(.12)$ & $(.12)$ \\
\hline \multirow[t]{2}{*}{ Constant } & $-4.07 * * *$ & $-2.15^{* * *}$ & $-2.09 * * *$ & $-2.98 * * *$ & $-2.47^{* * *}$ \\
\hline & $(.23)$ & $(.31)$ & $(.29)$ & $(.32)$ & $(.31)$ \\
\hline Observations & 2,682 & 2,168 & 2,109 & 2,164 & 2,121 \\
\hline Log Likelihood & $-1,573.14$ & $-1,026.03$ & $-1,128.67$ & -983.83 & -988.90 \\
\hline
\end{tabular}

Notes: ${ }^{*} \mathrm{p}<0.1 ; * \mathrm{p}<0.05 ; * * \mathrm{p}<0.01$. 
Table A6. Models (1) to (5) replicate the models in Table 1 in the manuscript but includes a respondents' evaluation of the nation's as well as their own economic situation.

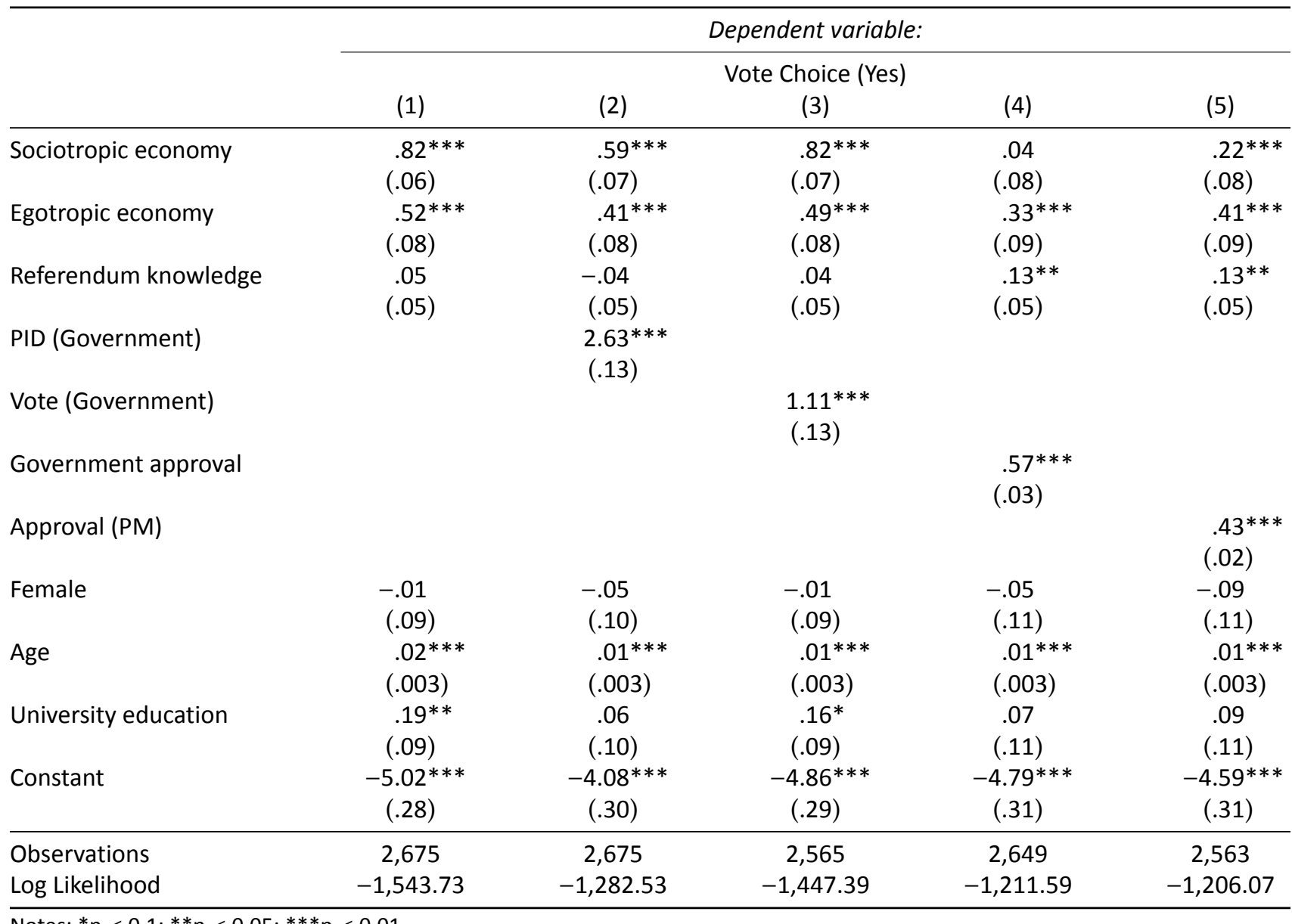

Notes: ${ }^{*} \mathrm{p}<0.1 ;{ }^{* *} \mathrm{p}<0.05 ; * * \mathrm{p}<0.01$. 
Table A7. Model mirrors model 1 in Table 1 in the manuscript but interacts a respondent's economic evaluation with their party identification (PID), distinguishing between a PID with one of the governing parties, the base category, with no party or with one of the opposition parties. This model is functionally equivalent to the subsample analyses presented in Table 2 in the manuscript.

\begin{tabular}{|c|c|}
\hline & Dependent variable: \\
\hline & Vote \\
\hline Sociotropic economy & $\begin{array}{l}.54^{* * *} \\
(.15)\end{array}$ \\
\hline Sociotropic economy PID (None) & $\begin{array}{c}.27 \\
(.19)\end{array}$ \\
\hline Sociotropic economy PID (Opposition) & $\begin{array}{c}.21 \\
(.18)\end{array}$ \\
\hline PID (None) & $\begin{array}{c}-2.69 * * * \\
(.56)\end{array}$ \\
\hline PID (Opposition) & $\begin{array}{c}-3.71 * * * \\
(.52)\end{array}$ \\
\hline Knowledge & $\begin{array}{l}-.07 \\
(.05)\end{array}$ \\
\hline Female & $\begin{array}{c}-.20 * \\
(.11)\end{array}$ \\
\hline Age & $\begin{array}{l}.01^{* * *} \\
(.003)\end{array}$ \\
\hline University education & $\begin{array}{c}.05 \\
(.11)\end{array}$ \\
\hline Constant & $\begin{array}{l}-.13 \\
(.48)\end{array}$ \\
\hline $\begin{array}{l}\text { Observations } \\
\text { Log Likelihood }\end{array}$ & $\begin{array}{c}2,599 \\
-1,193.78\end{array}$ \\
\hline
\end{tabular}

Notes: ${ }^{*} p<0.1 ; * * p<0.01$

Table A8. Models correlate a respondent's vote intention, instead of vote choice, with their evaluation of the national economy, separately for subgroups of respondents with a party identification with one of the governing parties (column 1), with no party identification (2) and with a party identification with one of the parties in opposition (3).

\begin{tabular}{|c|c|c|c|}
\hline & \multicolumn{3}{|c|}{ Subgroups: } \\
\hline & $\begin{array}{c}\text { PID (Government) } \\
\text { (1) }\end{array}$ & $\begin{array}{c}\text { PID (None) } \\
(2)\end{array}$ & $\begin{array}{l}\text { PID (Opposition) } \\
\text { (3) }\end{array}$ \\
\hline Sociotropic economy & $\begin{array}{l}1.08^{* * *} \\
(.20)\end{array}$ & $\begin{array}{l}.75 * * * \\
(.17)\end{array}$ & $\begin{array}{l}.78^{* * *} \\
(.10)\end{array}$ \\
\hline Knowledge & $\begin{array}{l}-.71^{* * *} \\
(.19)\end{array}$ & $\begin{array}{l}-.49 * * * \\
(.15)\end{array}$ & $\begin{array}{l}-.70 * * * \\
(.08)\end{array}$ \\
\hline Female & $\begin{array}{c}-.45 \\
(.31)\end{array}$ & $\begin{array}{c}.14 \\
(.27)\end{array}$ & $\begin{array}{c}.26 \\
(.17)\end{array}$ \\
\hline Age & $\begin{array}{l}.01^{*} \\
(.01)\end{array}$ & $\begin{array}{c}-.001 \\
(.01)\end{array}$ & $\begin{array}{c}-.01 * * \\
(.005)\end{array}$ \\
\hline University education & $\begin{array}{c}-.40 \\
(.29)\end{array}$ & $\begin{array}{c}-.37 \\
(.27)\end{array}$ & $\begin{array}{l}.03 \\
(.17)\end{array}$ \\
\hline Constant & $\begin{array}{l}-.13 \\
(.77)\end{array}$ & $\begin{array}{l}-.93 \\
(.66)\end{array}$ & $\begin{array}{l}-1.43^{* * *} \\
(.39)\end{array}$ \\
\hline Observations & 492 & 294 & 957 \\
\hline Log Likelihood & -162.51 & -183.74 & -469.21 \\
\hline
\end{tabular}

Notes: ${ }^{*} p<0.1 ; * p<0.05 ; * * * p<0.01$. 
Table A9. Models correlate a respondent's vote choice, with their evaluation of the national economy (measured after the referendum), separately for subgroups of respondents with a party identification with one of the governing parties (column 1), with no party identification (2) and with a party identification with one of the parties in opposition (3).

\begin{tabular}{|c|c|c|c|}
\hline & \multicolumn{3}{|c|}{ Subgroups: } \\
\hline & $\begin{array}{l}\text { PID (Government) } \\
\text { (1) }\end{array}$ & $\begin{array}{c}\text { PID (None) } \\
(2)\end{array}$ & $\begin{array}{c}\text { PID (Opposition) } \\
\text { (3) }\end{array}$ \\
\hline Sociotropic economy(after referendum) & $\begin{array}{l}1.00 * * * \\
(.16)\end{array}$ & $\begin{array}{l}.87^{* * *} \\
(.13)\end{array}$ & $\begin{array}{l}.97^{* * *} \\
(.10)\end{array}$ \\
\hline Knowledge & $\begin{array}{c}-.10 \\
(.13)\end{array}$ & $\begin{array}{c}-.12 \\
(.10)\end{array}$ & $\begin{array}{r}-.07 \\
(.08)\end{array}$ \\
\hline Female & $\begin{array}{c}-.37 \\
(.26)\end{array}$ & $\begin{array}{r}-.33 \\
(.20)\end{array}$ & $\begin{array}{r}-.08 \\
(.16)\end{array}$ \\
\hline Age & $\begin{array}{l}.04^{* * *} \\
(.01)\end{array}$ & $\begin{array}{l}.01^{* *} \\
(.01)\end{array}$ & $\begin{array}{l}.0004 \\
(.005)\end{array}$ \\
\hline University education & $\begin{array}{c}.12 \\
(.25)\end{array}$ & $\begin{array}{c}-.06 \\
(.20)\end{array}$ & $\begin{array}{c}.19 \\
(.16)\end{array}$ \\
\hline Constant & $\begin{array}{c}-2.79 * * * \\
(.70)\end{array}$ & $\begin{array}{c}-2.94^{* * *} \\
(.53)\end{array}$ & $\begin{array}{c}-4.09 * * * \\
(.38)\end{array}$ \\
\hline Observations & 647 & 556 & 1,394 \\
\hline Log Likelihood & -224.48 & -344.83 & -576.56 \\
\hline
\end{tabular}

Notes: **p $<0.05 ; * * *<0.01$.

Table A10. Models correlate a respondent's vote choice, with their evaluation of their own economic situations instead of the national economy, separately for subgroups of respondents with a party identification with one of the governing parties (column 1), with no party identification (2) and with a party identification with one of the parties in opposition (3).

\begin{tabular}{|c|c|c|c|}
\hline & \multicolumn{3}{|c|}{ Subgroups: } \\
\hline & $\begin{array}{l}\text { PID (Government) } \\
\text { (1) }\end{array}$ & $\begin{array}{c}\text { PID (None) } \\
(2)\end{array}$ & $\begin{array}{c}\text { PID (Opposition) } \\
\text { (3) }\end{array}$ \\
\hline Egotropic economy & $\begin{array}{l}.62^{* * *} \\
(.19)\end{array}$ & $\begin{array}{l}.71 * * * \\
(.15)\end{array}$ & $\begin{array}{l}.65^{* * *} \\
(.10)\end{array}$ \\
\hline Knowledge & $\begin{array}{c}-.03 \\
(.13)\end{array}$ & $\begin{array}{r}-.08 \\
(.10)\end{array}$ & $\begin{array}{c}-.11 \\
(.07)\end{array}$ \\
\hline Female & $\begin{array}{r}-.46^{*} \\
(.25)\end{array}$ & $\begin{array}{l}-.39 * * \\
(.19)\end{array}$ & $\begin{array}{l}-.08 \\
(.15)\end{array}$ \\
\hline Age & $\begin{array}{l}.03^{* * *} \\
(.01)\end{array}$ & $\begin{array}{c}.01 \\
(.01)\end{array}$ & $\begin{array}{l}.001 \\
(.004)\end{array}$ \\
\hline University education & $\begin{array}{c}.11 \\
(.24)\end{array}$ & $\begin{array}{c}-.03 \\
(.19)\end{array}$ & $\begin{array}{c}.22 \\
(.15)\end{array}$ \\
\hline Constant & $\begin{array}{c}-1.29 * \\
(.71)\end{array}$ & $\begin{array}{l}-2.39 * * * \\
(.54)\end{array}$ & $\begin{array}{l}-3.23^{* * *} \\
(.39)\end{array}$ \\
\hline Observations & 648 & 563 & 1,397 \\
\hline Log likelihood & -239.71 & -360.55 & -612.37 \\
\hline
\end{tabular}

Notes: ${ }^{*} p<0.1 ; * p<0.05 ; * * p<0.01$. 
Table A11. Models correlate a respondent's vote choice, with their evaluation of the national economy and that of their own economic situation, separately for subgroups of respondents with a party identification with one of the governing parties (column 1), with no party identification and with a party identification with one of the parties in opposition (3).

\begin{tabular}{|c|c|c|c|}
\hline & \multicolumn{3}{|c|}{ Subgroups: } \\
\hline & $\begin{array}{c}\text { PID (Government) } \\
\text { (1) }\end{array}$ & $\begin{array}{l}\text { PID (None) } \\
(2)\end{array}$ & $\begin{array}{l}\text { PID (Opposition) } \\
\text { (3) }\end{array}$ \\
\hline Sociotropic economy & $\begin{array}{l}.41 * * \\
(.16)\end{array}$ & $\begin{array}{l}.72^{* * * *} \\
(.14)\end{array}$ & $\begin{array}{l}.59 * * * \\
(.10)\end{array}$ \\
\hline Egotropic economy & $\begin{array}{l}.42^{* *} \\
(.21)\end{array}$ & $\begin{array}{l}.43^{* *} \\
(.17)\end{array}$ & $\begin{array}{l}.34^{* * *} \\
(.12)\end{array}$ \\
\hline Knowledge & $\begin{array}{l}-.06 \\
(.13)\end{array}$ & $\begin{array}{l}-.08 \\
(.10)\end{array}$ & $\begin{array}{l}-.10 \\
(.07)\end{array}$ \\
\hline Female & $\begin{array}{r}-.44^{*} \\
(.25)\end{array}$ & $\begin{array}{l}-.24 \\
(.20)\end{array}$ & $\begin{array}{l}-.11 \\
(.15)\end{array}$ \\
\hline Age & $\begin{array}{l}.03^{* * *} \\
(.01)\end{array}$ & $\begin{array}{l}.01 * \\
(.01)\end{array}$ & $\begin{array}{l}.002 \\
(.004)\end{array}$ \\
\hline University education & $\begin{array}{l}.09 \\
(.24)\end{array}$ & $\begin{array}{l}-.20 \\
(.20)\end{array}$ & $\begin{array}{l}.20 \\
(.16)\end{array}$ \\
\hline Constant & $\begin{array}{c}-1.90 * * \\
(.76)\end{array}$ & $\begin{array}{c}-3.64^{* * *} \\
(.62)\end{array}$ & $\begin{array}{l}-3.99 * * * \\
(.43)\end{array}$ \\
\hline Observations & 647 & 557 & 1,391 \\
\hline Log likelihood & -236.56 & -342.48 & -592.36 \\
\hline
\end{tabular}

Notes: ${ }^{*} \mathrm{p}<0.1 ;{ }^{* *} \mathrm{p}<0.05 ; * * \mathrm{p}<0.01$

Table A12. Sociotropic economic evaluations (pre-referendum wave), sociotropic economic evaluations (post-referendum wave), egotropic economic evaluations (post-referendum wave only), in the rows, and vote choice, in the columns.

\begin{tabular}{|c|c|c|c|c|c|}
\hline 0 & 1 & 0 & 1 & 0 & 1 \\
\hline 0.86 & 0.14 & 0.88 & 0.12 & 0.87 & 0.13 \\
\hline 0.78 & 0.22 & 0.82 & 0.18 & 0.80 & 0.20 \\
\hline 0.53 & 0.47 & 0.59 & 0.41 & 0.54 & 0.46 \\
\hline 0.25 & 0.75 & 0.16 & 0.84 & 0.38 & 0.62 \\
\hline 0.32 & 0.68 & 0.26 & 0.74 & 0.29 & 0.71 \\
\hline
\end{tabular}

Table A13. Number of false and correct predictions when always predicting the "Mode" ("No"), using a simple "Reduced" regression model without the economy variable, the "Full model" reported in the paper. For predictions based on the regression models a simple is applied stipulating that prediction above .5 are treated as 1 ("Yes") and prediction below .5 as 0 ("No").

\begin{tabular}{lrr}
\hline & False & Correct \\
\hline Mode & 1046 & 1636 \\
Reduced model & 1032 & 1650 \\
Full model & 827 & 1855 \\
\hline
\end{tabular}




\section{COGITATIO}

Table A14. Reduced model, model (1) from Table 1 in the manuscript but without the economic evaluations, and the full model, model (1) from Table 1 in the manuscript with the economic evaluations.

Dependent variable: Vote choice (Yes)

(1)

(2)

Sociotropic economy $1.00 * * *$

$(.06)$

Referendum knowledg

$.11^{* * *}$

$.07 *$

Government approval

(.04)

(.04)

Female

$-.08$

$-.01$

(.08)

(.09)

$.01 * * *$

$.02 * * *$

(.002)

(.003)

Age

$.33 * * *$

$.20 * *$

(.08)

(.09)

University education

$-1.30 * * *$

$-4.07^{* *}$

\begin{tabular}{lr} 
& $(.15)$ \\
\hline Observations & 2,697 \\
Log likelihood & $-1,772.12$
\end{tabular}

(.23)

Log likelihood

$-1,772.12$

2,682

Notes: ${ }^{*} \mathrm{p}<0.1 ;{ }^{* *} \mathrm{p}<0.05 ;{ }^{* * *} \mathrm{p}<0.01$ 


\section{COGITATIO}

\section{Appendix II}

\section{Pre-referendum wave}

S18 (sociotropic economic evaluation)

\section{Original}

Parliamo di economia. Secondo Lei la situazione economica in Italia nell'ultimo anno è:

1. Molto migliorata

2. Abbastanza migliorata

3. Rimasta eguale

4. Abbastanza peggiorata

5. Molto peggiorata

6. Non saprei

\section{English}

Speaking of the economy, do you think the economic situation in Italy in the last year:

1. Improved a lot

2. Improved somewhat

3. Remained equal

4. Got a little worse

5. Got much worse

6. I do not know

\section{S20 (government approval)}

\section{Original}

Come valuta l'operato del governo guidato da Matteo Renzi, in una scala da 0 a 10 (dove 0 = 'giudizio completamente negativo' e 10 = 'giudizio completamente positivo')?

1. 0 = giudizio completamente negativo

2. 1

3. 2

4. 3

5. 4

6. 5

7. 6

8. 7

9. 8

10. 9

11. 10 = giudizio completamente positivo

12. Non saprei

\section{English}

How do you assess the work of the government led by Matteo Renzi, on a scale of 0 to 10 (where $0=$ 'completely negative view' and 10 = 'totally positive view')?

1. $0=$ completely negative judgment

2. 1

3. 2

4. 3

5. 4 


\section{5}

7. 6

8. 7

9. 8

10. 9

11. $10=$ totally positive view

12. I do not know

\section{S30 (Knowledge question 1)}

\section{Original}

Qual era il quorum (soglia di partecipazione) necessario affinch'e il referendum fosse valido?

- La meta (50\%) degli elettori

- I due terzi (66\%) degli elettori

- Non c'e una soglia: il referendum sar'a valido qualunque sia il numero di votanti

\section{English}

What is the quorum (participation threshold) necessary for the referendum to be valid?

- Half (50\%) of voters

- Two-thirds (66\%) of voters

- There is no threshold: the referendum will be valid whatever the number of voters

S31 (Knowledge question 2)

\section{Original}

La riforma costituzionale prevede che:

1. I senatori non fossero piu' eletti direttamente dagli elettori

2. Una riduzione dei membri della Camera dei Deputati

3. L'abolizione del senato e un Parlamento con una sola Camera

English The constitutional reform provides that:

1. The senators are not elected directly by voters anymore

2. A reduction of the members of the Chamber of Deputies

3. The abolition of the Senate and a Parliament with a single Chamber

\section{S32 (Knowledge question 3)}

Original La riforma costituzionale prevede di:

1. Abolire il CNEL

2. Abolire il MIUR

3. Abolire la Cassa Depositi e Prestiti

\section{English}

The constitutional reform provides that:

1. Abolition of the CNEL

2. Abolition of the Ministry of Education

3. Abolition of the Cassa Depositi e Prestiti 
Post-referendum wave

D1 (sociotropic economic evaluation)

Original

Parliamo di economia. Secondo Lei la situazione economica in Italia nell'ultimo anno è:

1. Molto migliorata

2. Abbastanza migliorata

3. Rimasta eguale

4. Abbastanza peggiorata

5. Molto peggiorata

6. Non saprei

English

Speaking of the economy, do you think the economic situation in Italy in the last year:

1. improved a lot

2. improved somewhat

3. remained equal

4. got a little worse

5. got much worse

6. I do not know

D2 (egotropic economic evaluation)

\section{Original}

La situazione economica della sua famiglia 'e:

1. Molto migliorata

2. Abbastanza migliorata

3. Rimasta eguale

4. Abbastanza peggiorata

5. Molto peggiorata

6. Non saprei

\section{English}

The economic situation of your family:

1. improved a lot

2. improved somewhat

3. remained equal

4. got a little worse

5. got much worse

6. I do not know

D9 (left-right self-placement)

\section{Original}

Molta gente quando parla di politica usa i termini 'sinistr'a e 'destr'a. Qui sotto 'e riportata una fila di caselle che vanno da sinistra a destra. Pensando alle sue opinioni politiche, Lei in quale casella si collocherebbe?

1. Sinistra 
2.

3.

4.

5.

6.

7.

8.

9.

10. Destra

11. Non saprei

12. Preferisco non colocarmi

\section{English}

Many people when talking about politics use the words 'left and right'. Below is a row of boxes that go from left to right. Thinking about your political opinions, in which box would you place?
1. Left
2.
3.
4.
5.
6.
7.
8.
9.
10. Right
11. I don't know
12. I prefer to not say

D10 (left-right placement of parties)

\section{Original}

Pensando invece ai partiti politici, dove collocherebbe ognuno dei seguenti? Utilizzi sempre le stessa fila di caselle che va da sinistra a destra. Se non conosce il partito o non sa che risposta dare, indichi 'Non conosco il partit'o' o 'Non saprei.'

1. Partito Democratico

2. Forza Italia

3. Movimento 5 Stelle

4. Lega Nord

5. Nuovo Centrodestra

6. Fratelli d'Italia

7. Sinistra Italiana Opzioni di risposta:

1. Sinistra

2.

3.

4.

5.

6.

7.

8.

9.

10. Destra

11. Non conosco il partito

12. Non saprei 
Thinking instead of political parties, where would you put each of the following? Always use the same row of boxes that goes from left to right. If you do not know the party or do not know what answer to give, indicate 'I do not know the party' or 'I do not know.'

1. Partito Democratico

2. Forza Italia

3. Movimento 5 Stelle

4. Lega Nord

5. Nuovo Centrodestra

6. Fratelli d'Italia

7. Sinistra Italiana

1. Left

2.

3.

4.

5.

6.

7.

8.

9.

10. Right

11. I don't know the party

12. I don't know 